NBER WORKING PAPER SERIES

\title{
TARGETING MANAGERIAL CONTROL: EVIDENCE FROM FRANCHISING
}

\author{
Francine Lafontaine \\ Kathryn L. Shaw \\ Working Paper 8416 \\ http://www.nber.org/papers/w8416
NATIONAL BUREAU OF ECONOMIC RESEARCH
1050 Massachusetts Avenue
Cambridge, MA 02138

August 2001

We gratefully acknowledge financial support from the National Science Foundation (NSF) under grant SBR9312083, and from the University of Michigan Business School, for this research. We thank participants at the 2001 AEA meetings, the 1999 International Society for New Institutional Economics conference and the 1999 International Society of Franchising conference, and in workshops at the Yale Law School, the Universitat Pompeu Fabra, Cornell University, the Columbia Law School, the University of Toronto, ATOM at the University of Paris I, Harvard Business School, l'Université de Rennes I, and Pennsylvania State University for their helpful comments and suggestions. We also thank Wendy Petropoulos and Robert Picard for their invaluable assistance. The usual caveat applies. The views expressed herein are those of the authors and not necessarily those of the National Bureau of Economic Research.

(C) 2001 by Francine Lafontaine and Kathryn L. Shaw. All rights reserved. Short sections of text, not to exceed two paragraphs, may be quoted without explicit permission provided that full credit, including (C) notice, is given to the source. 
Targeting Managerial Control: Evidence from Franchising

Francine Lafontaine and Kathryn L. Shaw

NBER Working Paper No. 8416

August 2001

JEL No. L2, J4, L1, J3

\begin{abstract}
$\underline{\text { ABSTRACT }}$
Using an extensive longitudinal data set on franchising firms, we show that established franchisors manage their portfolio of company and franchised units to maintain a particular target level of corporate control and ownership of outlets. On average, established franchisors maintain about 15 percent of their outlets as company owned - with the other 85 percent owned by franchisees. Interestingly, the rate of company ownership does not rise or fall within firms as they gain experience or learn, or as they succeed or fail. However, the targeted rate does vary considerably across firms: firm-specific fixed effects explain 90 percent of the variance of company ownership rates in our longitudinal data. Given strong evidence that firms target specific, but different, rates of company ownership, what factors determine firms' optimal targeted rates? We find that brandname value is an important determinant: franchisors with high brandname value, as measured by advertising fees or major media expenditures, target high rates of company ownership. We argue that targeting high rates of company ownership is desirable in chains with more valuable brands because individual franchisees have incentives to free ride on brandname value. Consequently, high-value franchisors need to exert more direct managerial control over outlets in their chain. In addition, high company ownership rates give franchisors better incentives to maintain the value of their brand.
\end{abstract}

Francine Lafontaine

University of Michigan Business School

701 Tappan Street

Ann Arbor, MI 48109

and NBER

laf@umich.edu
Kathryn L. Shaw

GSIA

Carnegie Mellon University

Pittsburgh, PA 15213

and NBER

kathryn_shaw@cea.eop.gov 


\section{INTRODUCTION}

In franchised chains, individual outlets are managed either by company managers or by franchisees who own the outlet. When the outlet is operated corporately, the manager receives mostly a salary, and internal mechanisms are used to monitor his behavior (such as personnel evaluation and outlet-level performance data). When a franchisee owns a single outlet, he typically acts as the general manager, and is the residual claimant on the outlet's profits (minus the payments to the franchisor). The franchisor in this case does not monitor directly the franchisee's behavior nearly as much as she does the company manager's (see Lafontaine, 1992b and Bradach, 1995 and 1997). Thus, within franchising firms, very different incentives and monitoring mechanisms are used for people who are doing basically equivalent jobs. Furthermore, franchising firms differ considerably in the degree to which they rely on company ownership versus franchising - some chains are entirely franchised while others have a large proportion of outlets owned and controlled by the company directly.

An extensive empirical literature has addressed already the reasons why franchising firms choose the extent of company ownership that they do. ${ }^{1}$ However, prior studies have relied largely on cross-sectional data. In this paper, we use an extensive panel data set we have developed to address two main questions, namely: Do franchising firms change the extent to which they control outlets directly over time as they learn more about the underlying factors that influence the value of franchising? And secondly, why do some franchising firms choose to operate more outlets directly than others?

\footnotetext{
${ }^{1}$ Lafontaine (1992), Minkler and Park (1994), Scott (1995), and see Lafontaine and Slade (2001) for a review.
} 
Our data set is a very unbalanced panel that follows almost 5000 U.S. and Canadian franchisors for various intervals from 1980 through to 1997. Given this panel, we are able to do two primary things that were not doable in past research. First, we are able to detail for the first time the evolution of company ownership within firms, as they become older and better established. Second, in assessing the importance of various factors affecting the extent of company ownership, we are able to control for potentially unobserved firm-specific effects that may cause patterns to differ cross-sectionally as opposed to over time within firms.

We use non-parametric estimation techniques and spline functions to model the evolution of company ownership over time within franchised firms. We find that a significant decrease in company ownership occurs during the first few years after a firm becomes involved in franchising. This is consistent with empirical results currently in the literature (e.g. Gallini and Lutz (1992), Lafontaine (1992), Scott (1995), and Thompson (1994)). However, we show that the reason for this decline is quite simple: company ownership must fall in the first few years because it begins, for all firms that are just getting involved in franchising, at 100\%. We proceed to demonstrate that after some initial years of decline, the percent of total outlets that are company-owned is remarkably constant within firms over time. We conclude from this that dual distribution is an equilibrium strategy for these firms, one that they adopt as they balance incentive and control issues, or, put differently, to balance the benefits and costs of company ownership and franchising. ${ }^{2}$ Finally, we show that the stable level of company ownership varies significantly across sectors, but also across firms within sectors. We find a strong positive relationship between the "targeted" proportion of company ownership chosen by firms and

\footnotetext{
${ }^{2}$ See e.g. Bradach and Eccles (1987) and Bradach (1997) for synergy arguments suggesting that dual distribution, or contract mixing, is optimal in franchising.
} 
measures of the value of their brand. We argue that firms with strong, high-quality brandname strategies adopt higher targets of company ownership because they need to exert a greater degree of direct managerial control in their chain.

The paper proceeds as follows. In the next section, we very briefly highlight some of the theoretical arguments leading to predictions about how the proportion of company units should evolve within firms over time. Following that, we describe our data and introduce nonparametric and regression results that describe the within-firm evolution of the company ownership of outlets. Given our results showing the stability of company ownership percentages, we examine in Section 3 how firms successfully maintain these constant proportions. We analyze how and why the extent of company ownership varies across firms in Section 4. We draw implications from our results and conclude in Section 5.

\section{COMPANY OWNERSHIP WITHIN FIRMS OVER TIME}

\subsection{A BRIEF OVERVIEW OF THE LITERATURE}

Several existing theoretical explanations for franchising imply that the extent of company ownership in these chains should change systematically as they become better established. Some models, for example, assume that franchising is more profitable than company ownership, but that firms must operate some units directly either to signal the high quality of their business format and distinguish themselves from the low-quality firms (Gallini and Lutz, 1992) or to credibly commit to upholding the value of the brandname (e.g. Scott, 1995). In these models, firms want to reduce their extent of company ownership over time as their quality level is revealed, or as they "develop a reputation for maintaining a certain level of quality" (Scott, 1995, p. 76). Other models of franchising, by contrast, assume instead that company ownership is the preferred mode of operation, but that franchising allows firms to obtain access to some scarce 
resource, either capital (Caves and Murphy, 1976), managerial talent (Norton, 1988), or local information (Minkler, 1990). As they become established and thus able to access these resources directly, firms in these models want to reduce their reliance on franchising. In other words, these models predict that the proportion of company ownership in a chain will grow over time. Finally, most agency models of franchising have little to say about the extent of company ownership in these chains as they focus instead on the optimal sharing rules and imply that the terms of the franchise contracts should vary across units. Assuming, however, that franchisors use only two types of contracts, a franchising and a managerial employment contract, then these models imply that those units where high-powered incentives for the franchisees are very valuable will be franchised, while others will be operated under a managerial employment contract. The extent of company ownership in a chain then is a passive outcome arising from outlet and franchisee heterogeneity in these models, and there is no expectation that the proportion of company ownership should do anything systematic as firms become established. (See Lafontaine and Slade, 2001, for more on this.)

A number of authors, including Gallini and Lutz (1992), Lafontaine (1992), Martin (1988), Minkler and Park (1994), Scott (1995), and Thompson (1994), have examined the relationship between the proportion of company outlets and franchisor age. Using crosssectional data, most have found evidence of a systematic decrease in the proportion of company ownership as firms become established. Gallini and Lutz (1992) and Scott (1995) interpret these results as evidence supporting the signaling or reputation effects described above.

\subsection{THE DATA}

Our extensive longitudinal data set allows us to revisit this issue empirically in a much more precise way. We have information from 1980 through 1997 for more than 1000 franchisors 
per year, resulting in a total sample size of 19162 observations. The data contain information on 1) the number of company-owned and franchised outlets, 2) the years of business and franchising experience, 3) the royalty rates, advertising fees and franchise fees, and 4) a set of variables describing some features of the franchisor, such as the amount of capital required to open an outlet, and the type of business it is involved in. Our data set is a very unbalanced panel. Though the number of franchisors included each year is rather stable, those firms that appear are not the same from one year to the next. We have a total of 4842 different franchisors in our data set, and so only about 4 observations per firm on average. ${ }^{3}$

Table 1 gives descriptive statistics for the main variables of interest for our overall sample of 19162 observations.

TABLE 1: DESCRIPTIVE STATISTICS

\begin{tabular}{lcccc}
\hline Variable Name & Mean & $\begin{array}{c}\text { Standard } \\
\text { Deviation }\end{array}$ & Minimum & Maximum \\
\hline Number of Franchised Units & 172.64 & 638.92 & 0 & 15394 \\
Number of Company Units & 35.05 & 234.05 & 0 & 4982 \\
Total Outlets & 207.69 & 788.15 & 1 & 19599 \\
Percent Company Owned & .222 & .287 & 0 & 1 \\
Years of Franchising Exp. & 10.56 & 9.84 & 1 & 77 \\
Years in Business & 17.33 & 15.21 & 1 & 175 \\
\hline
\end{tabular}

\subsection{Changes in the Percent of Company OWnership as Firms Gain EXPERIENCE: Cross-SeCTIONAL RESUltS}

As a first step towards examining the evolution of vertical integration in franchised chains, we show in Figure 1 the mean value of the percent company owned as a function of years of franchising experience. We do this in Figure 1a for the overall sample, and then separately for

\footnotetext{
${ }^{3}$ See the Data Appendix for more on the sources of the data and a detailed breakdown of the number of firms we observe over different time frames.
} 
chains with more than and less than the average number of outlets. In Figure 1b, we divide the sample based on whether the firm is about to exit franchising or not, whereas in Figure 1c and 1d, we focus on different growth rates and different sectors respectively. Each time, we use all the data and treat each observation as a separate piece of information. In other words, we do not distinguish between cross-sectional or longitudinal patterns, and so the figure is dominated by the cross-sectional effects.

Figure 1A: THE PROPORTION OF COMPANY UNITS AS A FUNCTION OF FIRM EXPERIENCE AND CHAIN SIZE

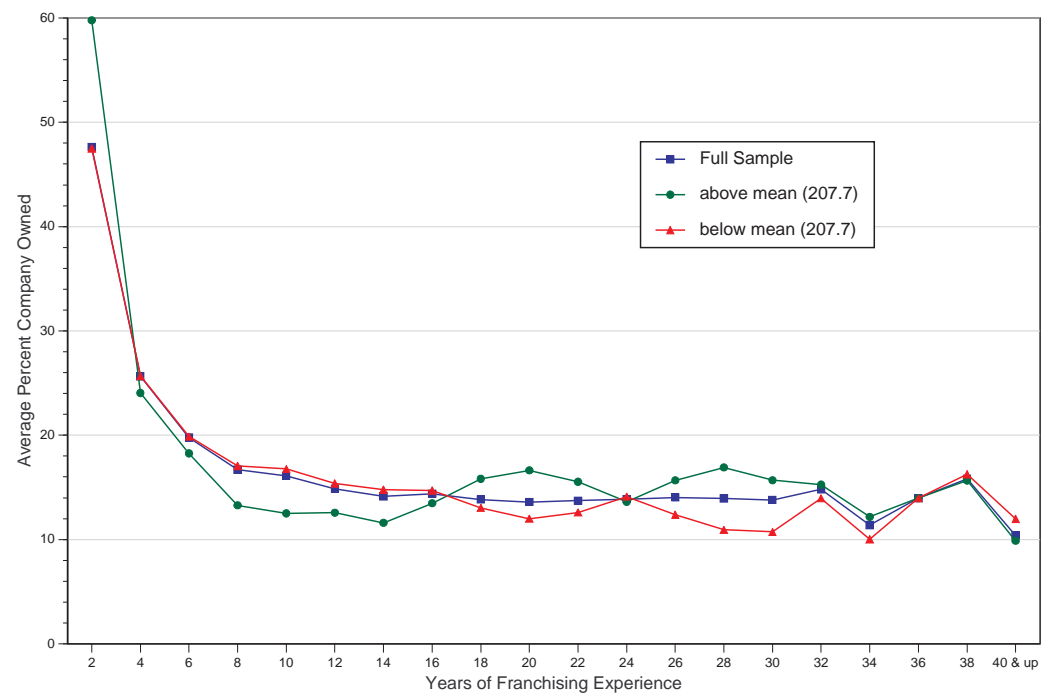

Figure 1B: The Proportion OF COMPANy UNITS AS A FUNCTION OF FIRM EXPERIENCE AND EXIT

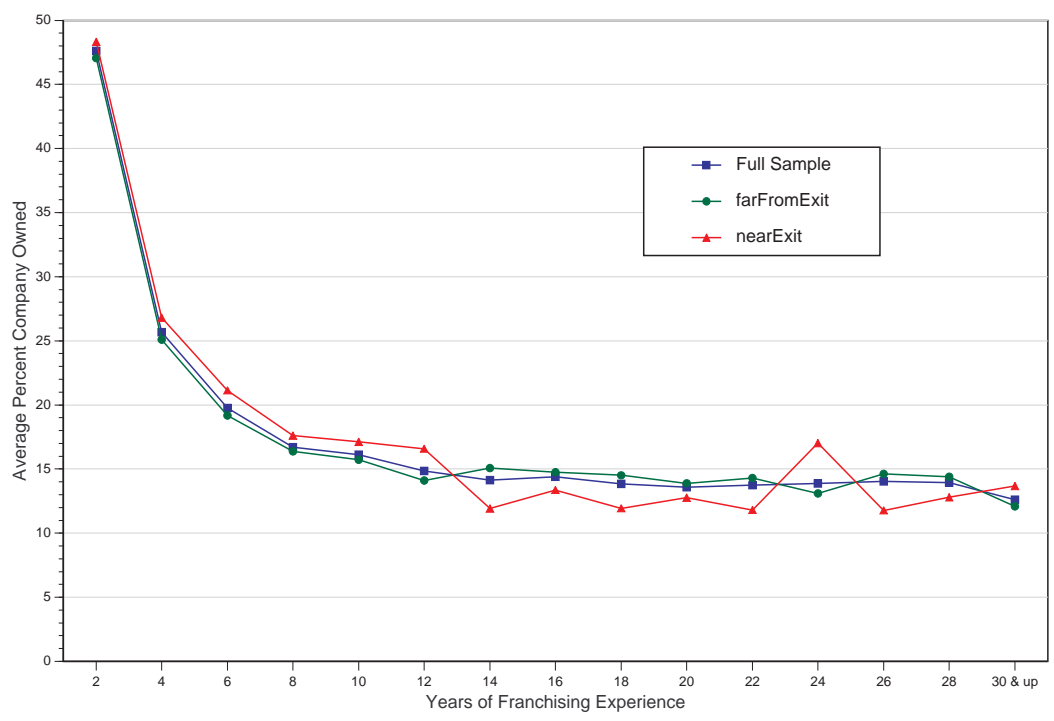


Figure 1C: The Proportion OF COMPANy Units AS A

FUNCTION OF FIRM EXPERIENCE AND GROWTH

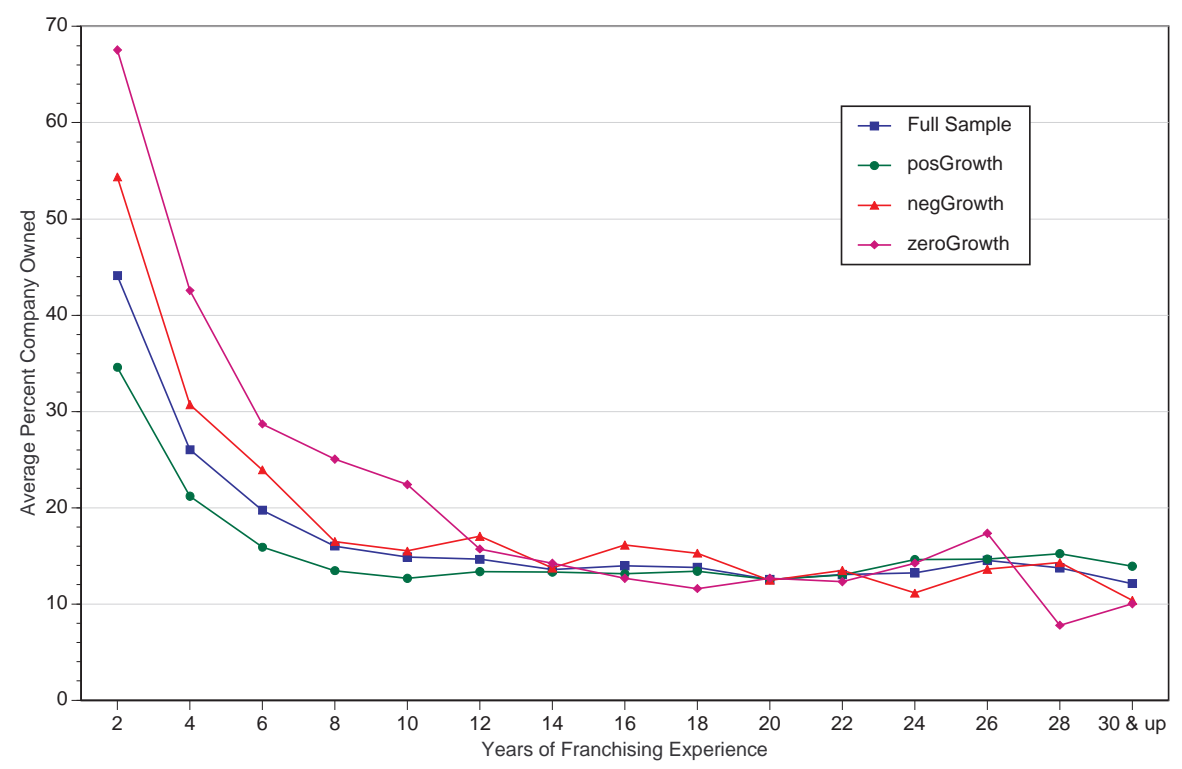

Figure 1D: The Proportion OF COMPANY UNITS AS A FunCTION OF FIRM EXPERIENCE AND BUSINESS ACTIVITY

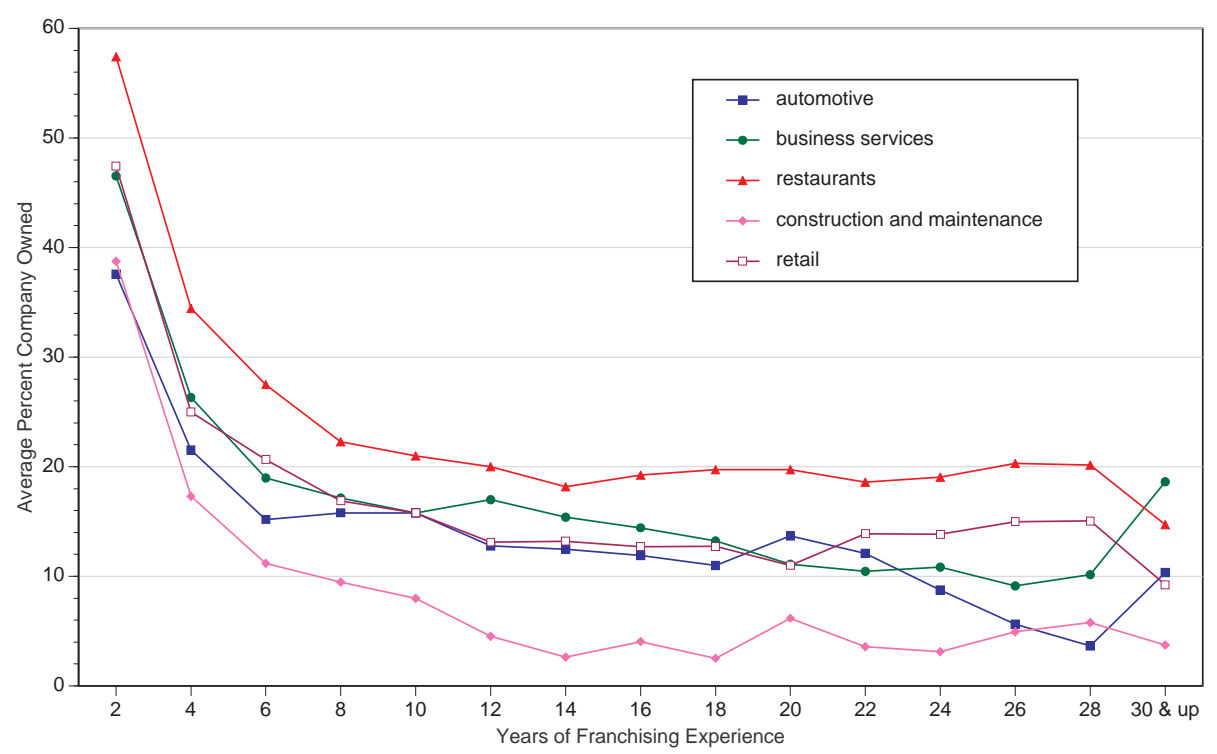

There are three striking features in Figure 1. First, no matter what sample one focuses on, the percent of company ownership falls precipitously during the first eight or so years in franchising. This is not surprising: Firms almost always begin franchising after having opened a few company-owned outlets, and so they are almost always $100 \%$ company owned initially. Thus, this proportion must fall in the early years in franchising, and we see that indeed it does 
fall sharply. Note that this pattern is the source of the negative relationship between franchising experience and company ownership that has been picked up to date in cross-sectional analyses. ${ }^{4}$ The second striking feature in Figure 1 is that after this initial decline, the percent company owned stabilizes in our overall sample and most sub-samples at a surprisingly constant rate of $15 \%$ on average. Thus, we see signs that firms are holding their proportion of company ownership quite fixed once they have reached a "target" level - which, on average, is clearly neither 0 nor $100 \%$. Finally, we see that the "stable" level of company ownership is the same for firms of differing success levels as captured by the size of the chains, their "near exit" status or not, and their growth rates. The one dimension along which we find different "targets" of company ownership is the firm's sectors of operation. In fact, we picked the sectors depicted in Figure 1d specifically to highlight the differences in the "targets." The figure clearly shows that restaurant chains stabilize at a relatively high proportion of company units, while the construction and maintenance sectors show a very low "stable" reliance on company ownership.

\subsection{Changes in the Percent of Company OWnership as Firms Gain EXPERIENCE: LONGITUDINAL RESULTS}

Figure 1 displayed cross-sectional patterns in the extent of company ownership, and showed, for example, that all the firms that have 10 years of franchising experience have an average percentage of company-owned units of $15 \%$ and that firms that have 11 years of experience also have 15 percent company units. But these mean values could hide important within-firm changes over time. For example, the constancy of the mean value of the percent

\footnotetext{
${ }^{4}$ Consistent with these cross-sectional analyses, if we fit a regression to our overall sample with a quadratic, cube and quartic term, and even higher order terms, we always find that the first-order term in the regression is large and negative. Furthermore, we find all higher-order terms to be significant, despite the fact that the raw data reveal a clear lack of systematic pattern after the initial period of decline. In other words, those various terms are picking up small variation in the data and given our very large sample, each of these is statistically significant.
} 
company owned could mask a decline for some firms that is offset by an increase for others. In this section, we model the within-firm evolution of ownership, namely

$$
\Delta \mathrm{C}_{\mathrm{it}}=\mathrm{f}(\text { franchising experience })_{\mathrm{it}}+\mathrm{e}_{\mathrm{it}}
$$

where $\Delta \mathrm{C}_{\mathrm{it}}$ is the within-firm change in the percent company owned for firm $\mathrm{i}$ at time $\mathrm{t}$, which varies as a function, $f$, of franchising experience. The residuals $e_{i t}$ represent unexplained variation in ownership patterns. In what follows, the function ' $f$ ' is estimated first using nonparametric, and then with parametric methods.

\subsubsection{Non-parametric Results}

Using Kernel regression, we show in Figure 2 how the change in company ownership within firms relates to franchising experience. The graph shows results obtained with different bandwidths, from two to five years of experience, and how the results compare to a straight line at 0 . Though this is not easy to perceive from the graph, as one would expect, the results become smoother as the bandwidth widens. ${ }^{5}$

What is most remarkable about Figure 2 is that the change in the percentage of companyowned units flattens out at zero at about 8 years of franchising experience. In other words, from that point on, the average firm makes no more changes in its proportion of company units. This remains true when we look at sub-samples of the data as we did before, namely for firms with positive, negative, and zero rates of growth, or for firms with above and below average numbers of outlets, or for firms within 3 years of exiting or not, or for firms in the five sectors defined earlier. In all cases, when looking at changes in the percentage of company ownership as firms gain experience, the change settles at zero after about 8 years of franchising experience.

\footnotetext{
${ }^{5}$ See Salgado-Ugarte, Shimizu and Taniuchi (1993) for more on bandwidth or "smoothing parameter" choices.
} 
Figure 2: Kernel Results for the Change in Percent Company Owned FOR DIFFERENT BANDWIDTHS $(2,3,4,5)$

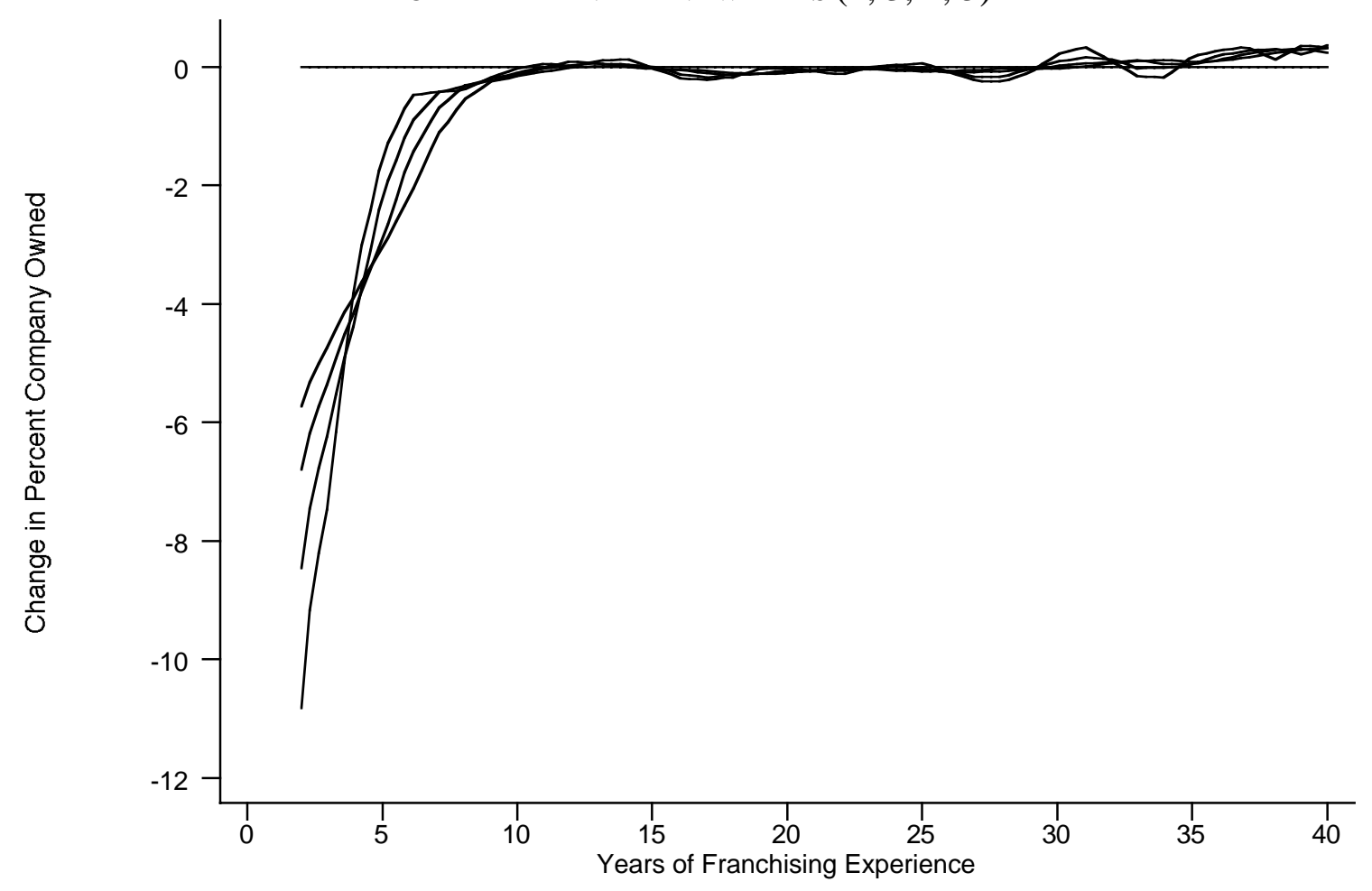

\subsubsection{Parametric Regression Results}

We use the patterns evident in the graphs above to construct reasonable parametric spline functions that model the change in percent company-owned units as firms gain experience. The chief advantage of the parametric approach is that we can easily devise statistical tests to answer two questions: 1) do the percentages of company ownership really stabilize over time, as they seem to? And 2) are there significant differences across sectors or other sub-samples of firms in the extent to which they stabilize?

The regression model that we estimate, and whose results are shown in Table 2, introduces a simple linear coefficient on experience in the regression of the change in percent company-owned of (1), but this linear coefficient is allowed to vary by experience level. We permit three intervals for franchising experience: $1-3,4-7$, and 8 to 45 (the sample is truncated at 46 years of experience due to insufficient data beyond that). 


\section{TABLE 2: SPline REGRESSION RESUlTS FOR THE CHANGE IN THE PROPORTION COMPANY OWNED}

\begin{tabular}{lcccc}
\hline Sample & $\begin{array}{c}\text { Number of } \\
\text { Obs. }\end{array}$ & \multicolumn{3}{c}{ Years of Franchising Experience } \\
& & $1-3$ & $4-7$ & $8-45$ \\
\hline FULL SAMPLE & 13022 & 6.42 & .431 & -.005 \\
& & $(24.81)$ & $(4.92)$ & $(-0.33)$ \\
GROWTH RATES: & & & \\
Positive & & & .588 & .013 \\
& & 6.69 & $(6.00)$ & $(0.64)$ \\
Negative & 3063 & $1.24 .22)$ & -.505 & -.045 \\
& & $(1.67)$ & $(-2.59)$ & $(-1.62)$ \\
Zero & 2102 & 1.68 & .403 & .001 \\
& & $(3.46)$ & $(2.19)$ & $(0.02)$
\end{tabular}

NEAR Exit STATUS:

$\begin{array}{lccrr}\text { Yes } & 4609 & 6.26 & .371 & .006 \\ & & (13.46) & (2.26) & (0.18) \\ \text { No } & 8413 & 6.58 & .465 & -.012 \\ & & (20.93) & (4.58) & (-0.63)\end{array}$

NUMBER OF UNITS:

$\begin{array}{lcccc}\text { Above Average } & 2579 & 1.62 & .435 & -.002 \\ & & (3.12) & (4.19) & (-0.21) \\ \text { Below Average } & 10443 & 6.51 & .439 & -.007 \\ & & (22.38) & (4.19) & (-0.26)\end{array}$

SECTOR:

\begin{tabular}{lcccc} 
Automotive & 1072 & 5.65 & .614 & -.011 \\
& & $(6.29)$ & $(2.10)$ & $(-0.20)$ \\
Business Services & 1592 & 3.09 & .468 & -.004 \\
& & $(4.28)$ & $(1.89)$ & $(-0.09)$ \\
Restaurants & \multirow{2}{*}{3466} & 4.29 & .734 & -.004 \\
& & $(8.03)$ & $(4.32)$ & $(-0.16)$ \\
Construction \& Maintenance & \multirow{2}{*}{1199} & 8.42 & .247 & .005 \\
& & $(9.85)$ & $(0.86)$ & $(0.08)$ \\
Retail & 2599 & 9.46 & -.082 & .023 \\
& & $(16.61)$ & $(-0.41)$ & $(0.50)$ \\
\hline
\end{tabular}

Note: t-statistics in parentheses.

The spline regression results in Table 2 reveal that after the first seven years of franchising experience, there is no significant variation in the percent of company ownership over time within firms. Furthermore, F-tests show that after the first seven years of experience, there are no significant differences in data patterns across sectors or for different sub-samples. 
The stabilization of the percentage of company-owned units occurs among all these sets of firms. Finally, we tested a large number of alternative spline functions, all of which were rejected by the data. For example, if we permit the linear relationship to vary within the experience levels 8 through 45, we find no significant effects. Thus, the data imply that there is no need for more cut-offs within this period.

\section{How do Firms Maintain this Constant Proportion of COMPANY OWNERSHIP?}

The results above show that the percentage of company ownership remains fixed after the early years of franchising. In this section, we examine how this is achieved. In other words, we ask whether we see this constancy because many firms are simply not expanding after their first few years in franchising, or whether this constancy occurs because firms make important changes in their number of company owned units as they grow or shrink the franchise side of their business.

In Figure 3a, we show the mean changes in the number of company and of franchised outlets respectively as firms gain experience. Concentrating on firms that are growing with age, we see that the change in the number of company-owned outlets rises over time. On average, during experience years 1 through 8, one or two company-owned outlets are added per year; during experience years 9 through 18, three to five company-owned outlets are added on average per year; and then for experience levels above that, ten to fifteen company outlets are added per year. Figure $3 \mathrm{~b}$ shows the accompanying change in the numbers of franchised outlets. Mostly, the combination of the two figures illustrates how firms, when growing or shrinking, change both their number of company owned and of franchised units significantly in the process of maintaining their constant overall proportion of company units. 
Figure 3A: The Change In THE Number of CoMPANy Units By EXPERIENCE LeVEL

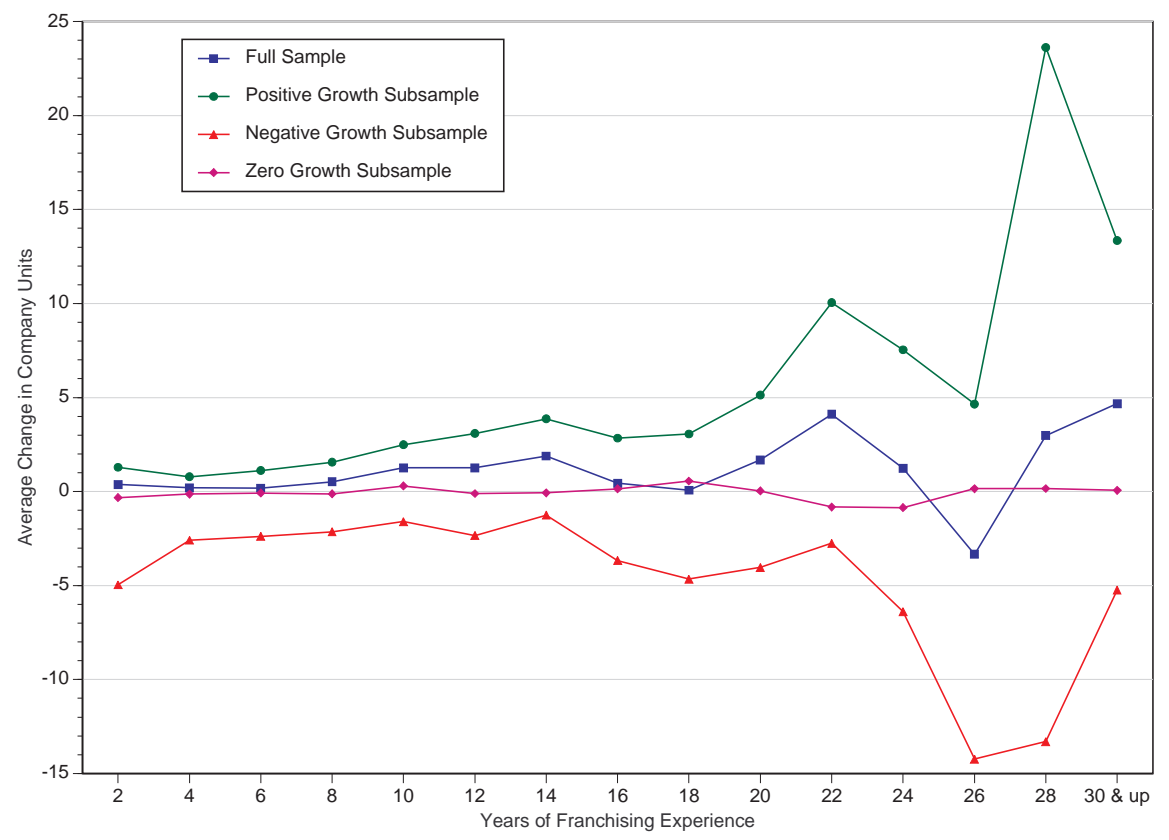

Figure 3B: The CHANGe IN THE NUMBER of FrANCHISED UNITS By EXPERIENCE LEVEL

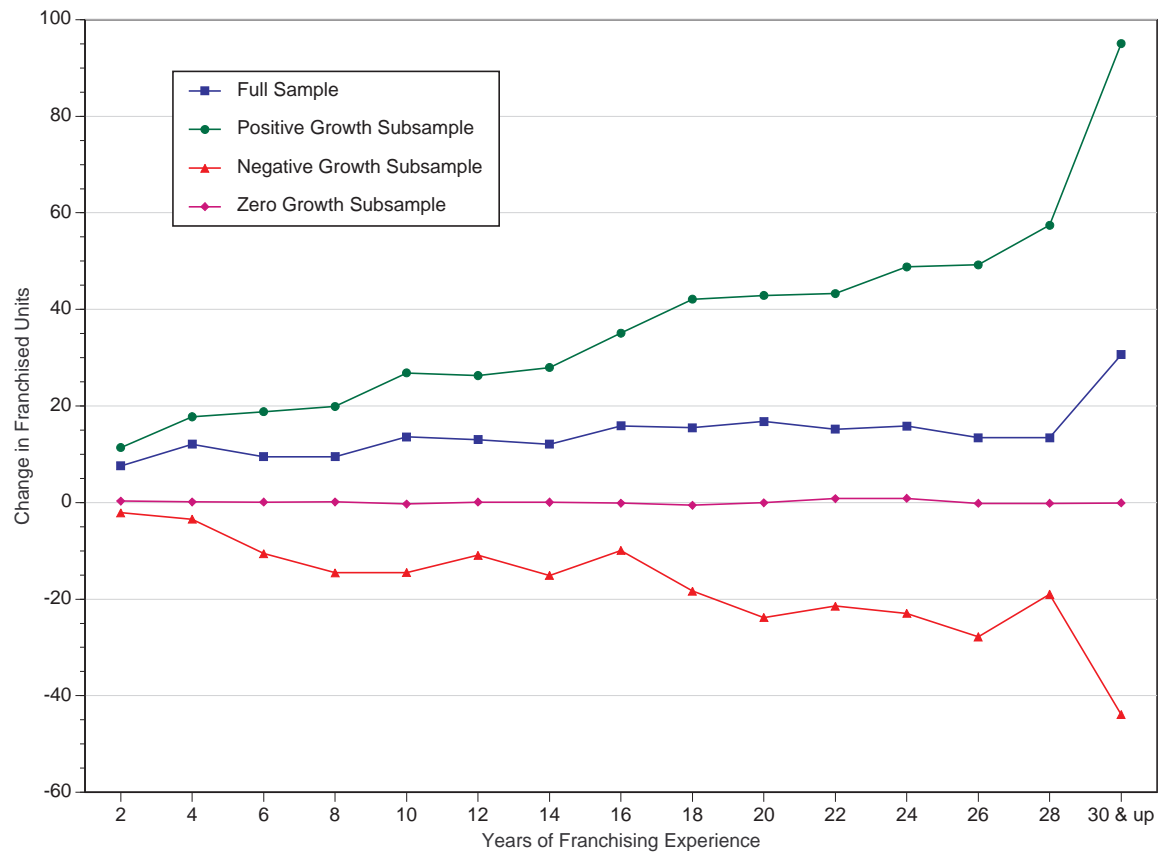

We conclude that the "stable" percentage of company units found above is not an artifact of lack of growth, but rather is achieved by firms via active management. In other words, when they add new units, they purposely add both company units as well as franchised ones to maintain their overall target of company-ownership. Thus, the proportion of company-owned 
units in these chains is not simply a passive outcome, which would arise simply from the combination of unit-level market characteristics and the need to choose the right contract for each unit, as agency theories would suggest. Rather, it is a decision variable that firms actively work toward. (See also Scott, 1995 on this.) On the other hand, these firms work towards a stable proportion that is neither 0 nor $100 \%$, thereby contradicting other theories that suggest they should be aiming for fully franchised or fully company-owned structures.

It is important to note that this conclusion, that firms target certain levels of company ownership, is consistent with companies' stated strategy, as reported in various sources. For example, Howard (1994), in his article on Burger King, refers to "the 7432-unit chain's goal to eventually own and operate just 10 percent of the system.” Similarly, Sasser and Pettway (1978) point out that "Wendy's expansion strategy was based on a "balanced" development of company-owned and franchised stores" (p. 104) and "Waffle House was expanding on two major fronts: company-operated units, and franchised units. (...) It was expected that an eventual balance of the system would be reached at 30 percent company stores and 70 percent franchise stores." (p. 139). Furthermore, the notion that firms set a goal for their proportion of company units is supported by the fact that franchisors, when asked, will answer questions concerning the "optimal" proportion of company units in a chain. Lafontaine and Kaufmann (1994) analyze survey data on this, and find that in most franchising firms, respondents believe that they operate what they perceive to be the optimal proportion of company units. The authors also note that in the vast majority of cases, this proportion is not 0 nor $100 \%$.

In its 1995 annual report, McDonald's gives reasons why it wants to operate units corporately. It states that "About $21 \%$ of McDonald's restaurants are operated by the Company. We maintain a global base of Company-operated restaurants to generate profits, link our interests with franchisees, develop management talent, gather research, and test ideas for better restaurant 
execution" (p. 11). We explore some of these arguments in our empirical analyses of the target level of company ownership in the next section.

Before turning to such analyses, we want to point out that our conclusion that franchisors choose a particular level of company ownership does not imply that they cannot also choose which units should be franchised and which should be company operated. Moreover, they can very well base this particular decision on local market and unit characteristics. Existing evidence strongly suggests that smaller, rural units that are farther away from headquarters are more likely than others to be franchised (see Lafontaine and Slade $(1997,2001)$ and the references therein). Thus local market and unit characteristics clearly affect the ownership decision. However, our results imply that a conscious decision to operate a certain proportion of units does inform or constrain the unit-level decisions on ownership.

\section{EXPLAining THE DifFerences in TARget LeVels OF COMPANY OWNERSHIP}

Thus far, we have shown that once franchisors become established, they target a constant level of company ownership - that is, the percent of outlets that are company owned is remarkably stable within firms over time. However, the target levels vary significantly across firms. The firm-specific nature of the company ownership targets can best be shown empirically as follows: if we restrict our sample to established franchisors (those with more than 7 years of franchising experience and at least 15 units) and run a regression of the percent of company ownership as a function of a set of explanatory variables and firm-specific fixed effects, the introduction of the firm-specific fixed effects raises the R-squared from $18.4 \%$ to $90.2 \%{ }^{6}$ Thus,

\footnotetext{
${ }^{6}$ The explanatory variables in the regression are those introduced in column 7 of Table 5 . They include 22 sector dummies that contribute 7.5 percentage points to the R-squared.
} 
it is clear from the data that different franchisors adopt strategies involving different targets. In this section, we address the question: What determines the target levels of company ownership that companies choose?

\subsection{Theoretical Arguments}

As noted earlier, basic incentive-cum-insurance models of franchising imply that the proportion of company units is a passive outcome that depends only on the characteristics of the set of outlets in the chain. Other models, such as signaling and reputation-based models imply systematic patterns up or down as firms become established, not the kind of stable "target" levels of company ownership that we observe. Thus, we must turn elsewhere for explanations of stable "target" levels of company ownership.

There are two main types of arguments in the literature that can explain differences in the extent of company ownership across firms and suggest factors that can influence this choice. The first relates to franchisee free-riding and the resulting need for the franchisor to control downstream operations. The second relates to franchisees' need to insure that their franchisors will not behave opportunistically once the contract is in place, namely that the franchisor will not under-invest in the brand. We briefly detail each of these and their empirical implications in the following section. Before turning to these, however, we note that several other models have been proposed to explain contract mixing. For example, Bai and Tao (2000) use a multi-tasking approach to argue that franchisors offer low-powered incentives (a company manager contract) to agents who are called upon to put effort in the generation of goodwill, and high-powered incentives (a franchise contract) to those who will put effort into sales generation. One implication of their model is that franchisors that require more goodwill effort will have to operate more company units. That is, unless the franchisor itself provides the goodwill effort, as 
is argued elsewhere in the literature. Other work by Bradach (1997) and Lewin (1998) emphasizes the synergies between company units and franchised units. For example, McDonald's affirms that it operates units directly in part to "gather research, and test ideas for better restaurant execution." In fact, franchisors not only can test ideas in company units, they can also use results from these units to demonstrate the profitability or feasibility of various ideas and innovations. In that sense, company units serve the roles of both information generation and diffusion within the franchised system. As suggested by the "window on the industry argument," company units also provide franchisors with information about individual markets, information that they may have more difficulty obtaining from other franchisees and that they can use to assess the behavior of individual franchisees. While all these models are of interest, they provide little guidance as to what the optimal mix of units is, and what it should relate to empirically. For that reason, we focus on the models below.

\subsubsection{Franchisor's Need for Control}

When firms choose to franchise, they give residual claimancy rights (after payment of royalties on sales) to their franchisees. This gives franchisees good incentives to keep costs down and sales up. Unfortunately, as pointed out e.g. by Brickley and Dark (1987) and Blair and Kaserman (1994), the residual claimancy status of the franchisees also gives them incentives to maximize their profits sometimes at the expense of the chain. For example, franchisees can choose to use lower quality inputs or offer less services to reduce their costs - they obtain the full increase in profits that results from these actions, but bear only part of the consequences of lower brandname value. Furthermore, franchisees may adapt their product offerings to better suit their local markets in ways that affect the value of the brand. In either case, franchisors will want to exert control and prevent these behaviors. 
Following Blair and Kaserman (1994), we illustrate the free-riding problem formally as follows. Define $\mathrm{p}=\left\{\mathrm{p}_{1}, \mathrm{p}_{2}, \ldots \mathrm{p}_{\mathrm{n}}\right\}$ and $\mathrm{s}=\left\{\mathrm{s}_{1}, \mathrm{~s}_{2}, \ldots \mathrm{s}_{\mathrm{n}}\right\}$ to be the price and service quality levels chosen by the $\mathrm{n}$ franchisees in the chain. Assume that every franchisee's profit level, $\pi_{\mathrm{i}}$, is a function of these two vectors, with $\partial \pi_{\mathrm{i}} / \partial \mathrm{p}_{\mathrm{j}}<0$ and $\partial \pi_{\mathrm{i}} / \partial \mathrm{s}_{\mathrm{j}}>0 .{ }^{7}$ For simplicity, assume that the franchisor's profits, $\Pi$, is derived as a simple share of each franchisee's profits, namely

$$
\Pi=\sum_{i=1}^{n} \delta\left(\pi_{i}(p, s)\right) .^{8}
$$

If $\delta=1, \Pi$ is total chain profits. To maximize the franchisor's (or chain's) profits, the service level chosen by franchisee $\mathrm{j}$ would have to satisfy

$$
\frac{\partial \Pi}{\partial s_{j}}=\sum_{i=1}^{n} \delta \frac{\partial \pi_{i}}{\partial s_{j}}=0
$$

which, given the constancy of $\delta$, can be rewritten as

$$
\frac{\partial \pi_{j}}{\partial s_{j}}=-\sum_{\substack{i=1 \\ i \neq j}}^{n} \frac{\partial \pi_{i}}{\partial s_{j}} .
$$

This level of franchisee service maximizes the franchisor's (or the chain's) profits, that is it takes into account the demand externalities and acts upon them. However, the individual franchisee, as a residual claimant, will want to maximize its unit's profits. This requires setting $\partial \pi_{\mathrm{j}} / \partial \mathrm{s}_{\mathrm{j}}=0$, which, of course, implies a lower service level than the one that maximizes the chain

\footnotetext{
${ }^{7}$ Note that intra-chain competition could imply $\partial \pi_{\mathrm{i}} / \partial \mathrm{p}_{\mathrm{j}}>0$ and $\partial \pi_{\mathrm{i}} / \partial \mathrm{s}_{\mathrm{j}}<0$. While units may compete with a few other units in their chain, for the majority of cases, the interdependence due to the shared brand dominates.

${ }^{8}$ We make the assumption that the franchisor's profits relates to the franchisee's in a simple way for simplicity. If we assumed instead that the franchisee pays a portion of its sales to the franchisor, the qualitative results would be unchanged. Similarly, an assumption that different units contribute differently to the franchisor's profits would not change the qualitative result of under-investment in activities where there are externalities.
} 
profits. Hence, from the overall chain's perspective, the franchisee under-invests in service provision activities. Similarly, the franchisee will under-invest when it comes to its pricing decisions, namely he will choose a price that is too high from the chain's perspective.

The issue, as just shown, arises from the fact that each franchisee's profits or demand level (and hence total demand for the chain) depends on decisions made by others in the chain. The stronger this dependence is (i.e. the larger is $\partial \pi / \partial \mathrm{s}_{\mathrm{j}}$ ), the more franchisee choices will diverge from those that would maximize the chain's profits. Yet franchising, by its nature, implies interdependence. In fact, this interdependence, which occurs through the brand, is a large part of what franchisees buy when they purchase a franchise. The more valuable the brand is, the more franchisees profit from it, and the more their revenues and profits are interrelated. Put differently, the more valuable the brand, the higher $\partial \pi_{\mathrm{i}} / \partial \mathrm{s}_{\mathrm{j}}$ and $\partial \pi_{\mathrm{i}} / \partial \mathrm{p}_{\mathrm{j}}$ will be. This, in turn, will lead to greater divergence between the service and price levels that franchisees choose compared to the levels that the franchisor wants them to use.

Note that if franchisees were not residual claimants, but were paid a fixed salary as corporate managers are, they would have no incentive to choose a different price and service level than the one requested by the franchisor. ${ }^{9}$ Thus, the divergence in prices and service levels amounts to a cost of using high-powered incentives for franchisees. This divergence, and hence the cost of using high-powered incentives, will increase with the extent of interdependence in the chain, or with the value of the brand.

\footnotetext{
${ }^{9}$ This assumes that they do not bear the cost of providing the requested service level. If they do, they will have incentives to shirk on service quality. This is the incentive problem that the franchisee's residual claimancy status is meant to address in the first place. We assume that franchisors can use other mechanisms to prevent shirking in company stores at least to some degree.
} 
The simple model above emphasizes differences in quality and price levels chosen by franchisees compared to what is optimal for the chain. This model thereby illustrates the standard "free-riding" argument against franchising. But as mentioned above, profit-maximizing franchisees may also rationally oppose the implementation of new production processes and new product offerings that they expect will not do well in their particular market - though the new method may be right for most other stores in the chain. Franchisees might also introduce products that are suited to their market, even though they are not suited to the chain as a whole. Such behaviors also hurt the value of the brand as branding is fundamentally linked to uniformity, in product offerings, service levels, prices, etc. These behaviors also are caused by the franchisee's residual claimant status, and as such represent a cost of franchising, a cost that grows with the value of the brand and the resulting need for consistency and uniformity.

Franchisors can impose various contractual restraints to curb the behaviors just described, such as requiring some minimum advertising and service levels, or imposing maximum prices, or by developing strict product mix guidelines. ${ }^{10}$ But such restraints are costly to enforce, and more to the point, may not prevent all the types of behaviors franchisors care about. To protect their brand further franchisors may need to exercise more direct managerial control over downstream operations. Vertically integrating with some of their units will offer franchisors the opportunity to control the behaviors just described directly in the integrated units, and indirectly in the franchised units. The indirect control arises from competition among corporate and franchised units, from the capacity to demonstrate the feasibility and profitability of new policies and new

\footnotetext{
${ }^{10}$ A 1997 court decision, State Oil v. Khan, has moved maximum resale prices to the rule of reason approach, making them for all intents and purposes legal. However, until this time, the imposition of maximum prices by franchisors was per se illegal, as were all forms of resale price maintenance.
} 
products, and, finally, from the market intelligence garnered from operating units directly. ${ }^{11}$

We conclude that whether it be in the form of the usual free-riding issue, or in the form of resisting change or adapting too much to local markets, the cost of franchisees maximizing their own unit's profits at the expense of those of the chain increases with the value of the brand. Ultimately, when this cost becomes large enough, firms will have a greater tendency to exert direct managerial control over downstream operations. Thus, we expect that the more valuable the brand, the higher the extent of company ownership should be.

\subsubsection{Aligning Franchisor Incentives}

A number of authors have emphasized the role of the franchisor in the ongoing value of the franchised business: the franchisor puts forth effort in advertising and promoting the brand, in monitoring franchisees, and in screening new franchisees, all of which are necessary for the long-term profitability of the chain. Models of franchising that have explicitly incorporated the franchisor's role (and the difficulty inherent in motivating his behavior) have shown that output sharing will be necessary to motivate the franchisor - or, as stated by McDonald's, to "link the franchisor's interests with those of its franchisees." This can be achieved, in a single franchisorfranchisee pair, with an appropriate choice of royalty rate (see e.g. Rubin, 1978, Lal, 1990, and Bhattacharyya and Lafontaine, 1995 for formal models). In that case, the more important is the effort of the franchisor in the production process, and the more difficult his role is to monitor, the more the franchisor should be given incentives, so the higher the royalty rate should be.

As noted in Lafontaine $(1992,1993)$ and Scott (1995), an alternative way to give the franchisor a stake in downstream operations, and thus incentives to maintain the value of the brand, is to have him operate units directly. If this is the mechanism by which the franchisor is

\footnotetext{
${ }^{11}$ This last aspect amounts to what is known as the "window on the industry" argument.
} 
given incentives, then the proportion of company units should be higher the more important the effort of the franchisor and the more difficult it is to monitor. Under the assumption that the role of the franchisor is to develop and uphold the value of the brand, the proportion of company units should increase with the importance of the brand in the success of the business. ${ }^{12}$

Finally, while agency arguments emphasize the incentive effects of the franchisor's stake or residual claims in the business, everything else constant, a larger proportion of franchisorowned units in the chain also gives franchisors incentives to perform if it means that they have more specific assets tied into the system. The need to protect these assets will motivate the franchisor to maintain the value of the brand and of the franchised system as a whole.

\subsection{The Model ANd DATa For TARgeting ANALySES}

The implication from both sets of arguments above is that in equilibrium, that is once they are established, franchisors will choose to operate more units directly the more valuable their brand is. Our primary hypothesis then is that:

Hypothesis: Franchising firms with higher tradename value will target a higher level of company ownership.

We test this hypothesis by estimating the following regression:

$$
\mathrm{P}_{\mathrm{it}}=\mathrm{aX} \mathrm{X}_{\mathrm{it}}+\mathrm{bZ} \mathrm{it}_{\mathrm{it}}+\mathrm{e}_{\mathrm{it}}
$$

where $P_{i t}$ is the percentage of company-owned outlets by firm i at time $t, X_{i t}$ is a vector of variables representing possible tradename value proxies, and $Z_{\text {it }}$ is a set of controls, such as sector dummies. The specification for the residual $\mathrm{e}_{\mathrm{it}}$ is described below.

\footnotetext{
${ }^{12}$ Franchisees indeed worry about large changes in this proportion (Bond, 1997). If the franchisor reduces its involvement downstream importantly, franchisees worry that he no longer will invest. Increases in this involvement can be interpreted as an increased probability that the franchisor is trying to take over downstream operations in an opportunistic way. Either way, change is worrisome.
} 
We explore the relationship between the target level of company ownership and the value of the tradename by restricting our sample to those firms and observations with 8 or more years of franchising, and 15 or more units. We do this because we wish to examine only those years when companies have grown enough to have reached their target levels-in the early one to seven years of franchising, the development of the first few franchised outlets must produce a drop in the percent company owned, as shown in Section 2 above. Table 3 shows descriptive statistics for this new "stable" sample.

We use three primary measures to assess the value of the brand: 1) the advertising fee, which is the $\%$ of their outlet sales that franchisees are required to pay to their franchisor for advertising purposes (Advertising), 2) the number of years the franchisor spent in business developing the system before beginning to franchise (Years Before Franchising), and 3) the amount of advertising dollars spent across major media for the brand (Media Exp.). The first two measures were collected from the same sources as all our other franchising data. However, they are not ideal proxies for tradename value, in that the advertising fee data is somewhat incomplete ${ }^{13}$, and Years Before Franchising could raise company ownership simply because a large volume of outlets are initially company owned. Thus, we sought a more accurate measure of tradename value, and collected the yearly media advertising expenditures reported in $\$ A d$ Summary for each brand in our "stable" sample from 1980 to 1997. (Other variables in Table 3 are described in Section 4.3).

\footnotetext{
${ }^{13}$ Our measure of advertising fees is the extra fee that some franchisees must pay to franchisors for advertising expenses. Some franchising firms (many in the early years of our data) absorb this fee in the required royalty rates that they charge franchisees and do not charge a separate advertising fee. Thus, our measure of advertising fee underestimates investments in advertising for an unknown number of firms.
} 
TABle 3: Descriptive StATISTICS FOR THE “StABLE” SAMPLE

\begin{tabular}{|c|c|c|c|c|c|}
\hline Variable & $\mathbf{N}$ & Mean & Std. Dev. & Min & Max \\
\hline$\%$ company owned & 7906 & .134 & .200 & 0 & 1 \\
\hline $\begin{array}{l}\text { Years Before(experience } \\
\text { before franchising) }\end{array}$ & 7906 & 7.86 & 10.93 & 1 & 128 \\
\hline Number of Outlets & 7906 & 396.49 & 1093.89 & 15 & 19599 \\
\hline Advertising ( $\%$ of sales) & 7906 & 1.57 & 1.87 & 0 & 13 \\
\hline Advertising /Outlet & 7906 & .021 & .039 & 0 & .469 \\
\hline Media Exp. (in $\$ 1000$ ) & 7906 & 2780.6 & 21445.2 & 0 & 598752.5 \\
\hline Media Exp./Outlet & 7906 & 2.28 & 7.46 & 0 & 259.7 \\
\hline Products Only & 7906 & .516 & .500 & 0 & 1 \\
\hline Business Only & 7906 & .091 & .288 & 0 & 1 \\
\hline Capital Required (\$) & 7670 & 231.89 & 1472.23 & 0 & 82500 \\
\hline \# of States franchising in & 5950 & 19.73 & 16.22 & 0 & 50 \\
\hline $\begin{array}{l}\text { Financing Available } \\
\text { (from franchisor) }\end{array}$ & 7779 & .688 & 1.054 & 0 & 4 \\
\hline Training (in days) & 5693 & 18.80 & 17.18 & 0 & 290 \\
\hline $\begin{array}{l}\text { Experience Required (of } \\
\text { franchisees) }\end{array}$ & 4073 & .271 & .444 & 0 & 1 \\
\hline Contract Length (years) & 3690 & 11.94 & 6.162 & 1 & 50 \\
\hline $\begin{array}{l}\text { \# of Employees (per } \\
\text { outlet) }\end{array}$ & 3547 & 9.21 & 13.48 & 0 & 150 \\
\hline
\end{tabular}

\subsection{SEMI-PARAMETRIC REgRESSION RESULTS}

We test our primary Hypothesis—-that high tradename value increases company ownership targets—by estimating regression (2) using several alternative functional forms. Results are shown in Table 4, using three different estimation techniques-OLS, Tobit, and a Tobit between estimator. As a point of comparison, we first present OLS results obtained using the whole "stable" sample. Then, in recognition of the fact that we have $26.2 \%$ of our PCENTC forming a mass point at zero in the "stable" sample, we present results obtained with a Tobit estimator. Finally, for the remainder of the regression results, we move to a between Tobit estimator, where we use firm-specific averages as data points and weigh each observation according to the number of observations per firm that is used to calculate the firm-specific 
averages. $^{14}$ We switch to the between estimator for one important reason-we have shown above that firms change their targeted level of company ownership very little over time. Thus using the full stacked data set can amount to the redundant use of multiple observations per company. Instead, by using the between estimator, we are emphasizing how tradename value matters as an explanation of the variation across firms in the data. This has the added advantage of "averaging" all our explanatory variables over time as well, making our media expenditure variable a less volatile and more representative measure of long-term investment in brand value.

The results in Table 4 show that tradename value, per all three of our measures, has a very significant positive effect on the extent of company ownership. Our three measures combined explain 13 percent of the variance of company ownership across firms, and the Media/outlet and Advertising/outlet explain 11 percent of this variance.

The most important effect arises from the value of Media Expenditures per outlet, where we have divided Media Expenditures by the number of outlets because large firms are likely to spend more on advertising than are small firms. ${ }^{15}$ The Media/outlet effect is estimated in a semiparametric quartic specification, given its theoretical importance and the statistical significance of all four non-linear terms - thus, the effect of Media/outlet rises, then plateaus, then rises again at substantially higher levels. ${ }^{16}$ The Media/outlet coefficients in the between-Tobit regressions imply a sizable impact: at the mean value of Media/outlet, a 10 percent increase in expenditures

\footnotetext{
${ }^{14}$ The typical between estimator does not use firm-specific weights reflecting the number of observations per firm, but between estimators are normally used for panel data that are balanced, thus this issue would not arise. For our unbalanced panel data set, measurement error is lower for these firms with more time-series data, and thus these should be more heavily weighted.

${ }^{15}$ If Media is included instead of Media/outlet, the significance of Media is essentially the same as Media/outlet.

${ }^{16}$ The effects of Media/outlet was also estimated in numerous other functional forms and the quartic was found to be superior. For example, when estimated in a spline function with seven break points in Media/outlet, the pattern in the coefficients is still quartic and there is no significant gain from the less constrained spline function relative to the quartic. We also plotted the predicted value of the effect of Media/outlet on PCENTC and find that the combined
} 
will create a 9.6 percent increase in company ownership, or increase the company ownership rate by .7 percentage point.

While Media/outlet has the predominant tradename value effect in our regressions, two other variables measuring tradename value are also highly significant. The variable Advertising/outlet, has a strong positive linear effect (squared terms are insignificant) across all estimated functional forms. ${ }^{17}$ Similarly, firms that developed more experience and thus higher tradename value prior to franchising (as measured by number of years in business before franchising) are more likely to have higher levels of company ownership. Of course, it is also the case for these firms that they were more likely to have begun franchising with a more sizable number of company-owned outlets.

In these regressions, we introduce several sets of controls, for survey year (dummies for years 1980-1997), vintage (dummies for year in which the firm began franchising), and company size (total number of outlets). The vintage dummies show a significant pattern of rising company ownership rates. ${ }^{18}$ This result implies that more recent entrants into franchising have been targeting higher proportions of company ownership on average. This effect possibly reflects the increased maturity of industries in which franchisors operate, and the resulting increase in the importance of brandname value for new entrants in these industries. Turning to the company size variable, the number of outlets has a negative effect on company ownership in the basic Tobit model, but this effect disappears in models that control for sectors as well as in

\footnotetext{
linear-squared-cubic-quartic effects have sensible turning points, but the levels overshoot somewhat.

${ }^{17}$ The advertising variable is the advertising fee paid as a percentage of outlet sales, and it performs best in our regressions when it is divided by the number of outlets, suggesting that the advertising fee has a smaller impact on company ownership rates for large franchisors.

${ }^{18}$ The coefficient (t-statistic) on the linear year-started-franchising is .0014 (4.60) if this variable replaces franchising vintage dummies in column 2 of Table 4 . The franchising entry-year dummies are segmented into eight dummies as follows: 1927-59, 1960-64, 1965-69, 1970-74, 1975-79, 1980-84, 1985-89, 1990-97.
} 
the between models, suggesting again that there is no change in company ownership rates as firms age and grow.

TABle 4: PERCENT COMPANy OWNEd REGRESSIONS

\begin{tabular}{|c|c|c|c|c|c|}
\hline & OLS & Tobit & Tobit & $\begin{array}{c}\text { Tobit } \\
\text { Between }\end{array}$ & $\begin{array}{c}\text { Tobit } \\
\text { Between }\end{array}$ \\
\hline MEDIA/OUTLET & $\begin{array}{c}2.30 \\
(21.90)\end{array}$ & $\begin{array}{l}2.91 \\
(21.79)\end{array}$ & $\begin{array}{c}2.36 \\
(17.77)\end{array}$ & $\begin{array}{l}3.41 \\
(9.44)\end{array}$ & $\begin{array}{l}2.72 \\
(8.11)\end{array}$ \\
\hline$(\text { MEDIA/OUTLET) })^{2}$ & $\begin{array}{l}-.066 \\
(14.06)\end{array}$ & $\begin{array}{l}-.085 \\
(-14.32)\end{array}$ & $\begin{array}{l}-.069 \\
(-11.80)\end{array}$ & $\begin{array}{l}-.102 \\
(-5.87)\end{array}$ & $\begin{array}{l}-.086 \\
(-5.07)\end{array}$ \\
\hline$\left(\right.$ MEDIA/OUTLET) ${ }^{3}$ & $\begin{array}{l}.0006 \\
(11.04)\end{array}$ & $\begin{array}{l}.0007 \\
(11.42)\end{array}$ & $\begin{array}{l}.0006 \\
(9.48)\end{array}$ & $\begin{array}{l}.0009 \\
(4.21)\end{array}$ & $\begin{array}{l}.0008 \\
(3.95)\end{array}$ \\
\hline$\left(\right.$ MEDIA/OUTLET) ${ }^{4}$ & $\begin{array}{c}-.000001 \\
(-9.79)\end{array}$ & $\begin{array}{r}-.000002 \\
(-10.21)\end{array}$ & $\begin{array}{c}-.000001 \\
(-8.51)\end{array}$ & $\begin{array}{c}-.000002 \\
(-3.62)\end{array}$ & $\begin{array}{c}-.000002 \\
(-3.54)\end{array}$ \\
\hline $\begin{array}{l}\text { ADVERTISING/ } \\
\text { OUTLET }\end{array}$ & $\begin{array}{l}.364 \\
(6.36)\end{array}$ & $\begin{array}{l}.499 \\
(6.85)\end{array}$ & $\begin{array}{l}.325 \\
(4.40)\end{array}$ & $\begin{array}{l}.788 \\
(5.82)\end{array}$ & $\begin{array}{l}.351 \\
(2.20)\end{array}$ \\
\hline YEARS BEFORE & $\begin{array}{l}.393 \\
(10.11)\end{array}$ & $\begin{array}{l}.524 \\
(10.58)\end{array}$ & $\begin{array}{l}.541 \\
(11.29)\end{array}$ & $\begin{array}{l}.639 \\
(6.73)\end{array}$ & $\begin{array}{l}.456 \\
(4.98)\end{array}$ \\
\hline$(\text { YEARS BEFORE) })^{2}$ & $\begin{array}{l}-.0022 \\
(-3.51)\end{array}$ & $\begin{array}{l}-.0034 \\
(-4.41)\end{array}$ & $\begin{array}{l}-.0035 \\
(-4.65)\end{array}$ & $\begin{array}{l}-.0056 \\
(-4.28)\end{array}$ & $\begin{array}{l}-.0029 \\
(-2.01)\end{array}$ \\
\hline OUTLETS & $\begin{array}{c}-.102 \\
(-2.26)\end{array}$ & $\begin{array}{c}-.121 \\
(-2.11)\end{array}$ & $\begin{array}{l}.006 \\
(0.10)\end{array}$ & $\begin{array}{l}-.268 \\
(-1.52)\end{array}$ & $\begin{array}{c}-.075 \\
(-0.55)\end{array}$ \\
\hline$(\text { OUTLETS })^{2}$ & $\begin{array}{l}.0010 \\
(2.19)\end{array}$ & $\begin{array}{l}.0011 \\
(2.08)\end{array}$ & $\begin{array}{l}.0002 \\
(0.45)\end{array}$ & $\begin{array}{l}.0028 \\
(1.49)\end{array}$ & $\begin{array}{l}.0011 \\
(0.74)\end{array}$ \\
\hline SECTOR DUMMIES & No & No & Yes & No & Yes \\
\hline$\chi^{2}$ & & $\begin{array}{l}\chi^{2}(34)= \\
1048.54\end{array}$ & $\begin{array}{l}\chi^{2}(56)= \\
1714.96\end{array}$ & $\begin{array}{c}\chi^{2}(34)= \\
266.77\end{array}$ & $\begin{array}{c}\chi^{2}(56)= \\
383.31\end{array}$ \\
\hline $\mathrm{R}^{2}$ & .123 & & & & \\
\hline $\mathrm{N}$ & 7906 & 7906 & 7906 & 1563 & 1563 \\
\hline
\end{tabular}

t-statistics are in parentheses. Also in regression: Canadian dummy, year dummies (for 1980-1997), franchising entry-year dummies (see footnote 18). The full sample Tobits have 2070 observations censored at zero, and 5836 uncensored.The between sample Tobits have 266 observations censored at zero, and 1297 uncensored.

When we add sector effects to the regression, they are very significant as a group, suggesting that there are differences in the desirability of franchising across the different types of business activities (compare columns 2 and 3, and then 4 and 5), but they do not alter our conclusions on tradename value-tradename value increases company ownership within sectors 
as well as across sectors. ${ }^{19}$ There are sector-specific differences in the rate of company ownership, and these differences could be related to the different types of production functions involved, which put more or less weight on franchisor and franchisee input, and imply different levels of monitoring costs as well. We explore sectoral differences in more detail below.

In column 1 of Table 5, we replace the sector dummy variables with only two dummies, one for firms producing products only (as opposed to products and services, or services only) and one for those supplying only businesses (as opposed to individual consumers). Interestingly, we find that franchisors that sell a product for resale tend to rely on company ownership more than those that sell services. This is consistent with the theory that franchisors have more at stake and want to exert more direct control when they sell their product through resellers under their brand. Service franchised chains have considerably less company ownership on average—about $9 \%$ less. Service firms, such as dry cleaners or tax preparation businesses, also depend on franchisee behavior to maintain brandname value, but are on average likely to have less established brandnames (our media variable has a smaller mean for services) and to face more repeat business, which generates incentives at the local level for maintaining one's own reputation. ${ }^{20}$

\footnotetext{
${ }^{19}$ Specifically, the sector-specific dummy coefficients are as follows:

$\begin{array}{llll}\text { Automotive products } & .082^{* * * *} & \text { Real Estate } & -.096 * * *\end{array}$

$\begin{array}{llll}\text { Business Services } & .113^{* * *} & \text { Recreation } & .066\end{array}$

Business Supplies $\quad-.058 * * * \quad$ Rental $\quad .066$

$\begin{array}{lll}\text { Contractors } & -.020 * * * & \text { Repair }\end{array}$

Cosmetic Products \& Services $\quad .119^{* *} \quad$ Retail-Build Mat .091

Eating places-Full Service $\quad .262^{* * *} \quad$ Retail-Clothing $.146^{* * *}$

Eating places-Limited Service $\quad .158^{* * * *} \quad$ Retail-Food $.164 * * *$

Education $\quad-.012 * * *$ Retail-Furnishing $.143 * * *$

Health \& Fitness $\quad .240^{* * *} \quad$ Retail-Other .084**

Hotels and motels $\quad .150^{* * *} \quad$ Retail-Used $\quad .080$

$\begin{array}{llll}\text { Maintenance } & .015^{* * *} & \text { Travel } & .015^{* * * *}\end{array}$

Personal Services $\quad .120^{* * * *}$

These represent partial effects-holding constant all other variables in column 2 of Table 4 . *** is significant at the $1 \%$ level, and ** at the $5 \%$ level.

${ }^{20}$ While these results are consistent with maintaining brandname value and minimizing externalities and free-riding problems, they contradict the idea that service production requires more effort incentives than product reselling.
} 
TABle 5: Percent Company Owned Regressions

\begin{tabular}{|c|c|c|c|c|}
\hline & $\begin{array}{c}1 \\
\text { Between Tobit }\end{array}$ & $\begin{array}{c}2 \\
\text { Quantile } .33\end{array}$ & $\begin{array}{c}3 \\
\text { Quantile } .5\end{array}$ & $\begin{array}{c}4 \\
\text { Quantile } .67\end{array}$ \\
\hline MEDIA/OUTLET & $\begin{array}{c}3.14 \\
(9.50)\end{array}$ & $\begin{array}{c}.933 \\
(17.96)\end{array}$ & $\begin{array}{c}2.11 \\
(12.98)\end{array}$ & $\begin{array}{c}4.22 \\
(10.25)\end{array}$ \\
\hline$(\text { MEDIA/OUTLET) })^{2}$ & $\begin{array}{l}-.100 \\
(-5.93)\end{array}$ & $\begin{array}{l}-.0175 \\
(-7.22)\end{array}$ & $\begin{array}{c}-.053 \\
(-6.75)\end{array}$ & $\begin{array}{l}-.155 \\
(-7.99)\end{array}$ \\
\hline$(\text { MEDIA/OUTLET) })^{3}$ & $\begin{array}{l}.0009 \\
(4.66)\end{array}$ & $\begin{array}{l}.00013 \\
(4.82)\end{array}$ & $\begin{array}{l}.0004 \\
(4.43)\end{array}$ & $\begin{array}{l}.0016 \\
(7.33)\end{array}$ \\
\hline$(\text { MEDIA/OUTLET) })^{4}$ & $\begin{array}{c}-.000002 \\
(-4.19)\end{array}$ & $\begin{array}{c}-.0000003 \\
(-4.06)\end{array}$ & $\begin{array}{c}-.0000009 \\
(-3.62)\end{array}$ & $\begin{array}{c}-.0000043 \\
(-7.06)\end{array}$ \\
\hline ADVERTISING/OUTLET & $\begin{array}{c}.493 \\
(3.21)\end{array}$ & $\begin{array}{c}.324 \\
(14.60)\end{array}$ & $\begin{array}{l}.635 \\
(9.58)\end{array}$ & $\begin{array}{l}1.063 \\
(6.29)\end{array}$ \\
\hline YEARS BEFORE FRANCHISING & $\begin{array}{l}.444 \\
(4.73)\end{array}$ & $\begin{array}{c}.081 \\
(5.15)\end{array}$ & $\begin{array}{l}.213 \\
(4.57)\end{array}$ & $\begin{array}{l}.320 \\
(2.70)\end{array}$ \\
\hline$\left(_{\text {YEARS BEFORE FRANCHISING) }}^{2}\right.$ & $\begin{array}{l}-.003 \\
(-2.11)\end{array}$ & $\begin{array}{l}-.0006 \\
(-2.92)\end{array}$ & $\begin{array}{l}-.0021 \\
(-3.44)\end{array}$ & $\begin{array}{l}.0009 \\
(0.53)\end{array}$ \\
\hline OUTLETS/1000 & $\begin{array}{l}-.132 \\
(-0.97)\end{array}$ & & & \\
\hline$(\text { OUTLETS })^{2}$ & $\begin{array}{l}.0014 \\
(0.93)\end{array}$ & & & \\
\hline PRODUCT SECTORS & $\begin{array}{c}.077 \\
(7.03)\end{array}$ & & & \\
\hline BUSINESS SECTORS & $\begin{array}{l}.055 \\
(2.88)\end{array}$ & & & \\
\hline SECTOR DUMMIES & NO & NO & NO & NO \\
\hline$\chi^{2}$ & $\chi^{2}(36)=305.27$ & & & \\
\hline $\mathrm{R}^{2}$ & & .0528 & .081 & .120 \\
\hline
\end{tabular}

t-statistics in parentheses. Regressions are comparable to those of column 4 of Table 4. Also, in the regressions are: Canadian dummy, year dummies (1980-1997), franchising entry-year dummies (see footnote 18). Sample size is 1563 for these between regressions. The quartile regressions do not control for the masspoints at zero (they are not Tobits).

In Table 5, we explore the sectoral differences in more detail by looking at quantile regression analysis (columns 2-4). The firms in the upper two-thirds (or .67 quantile) of the distribution of PCENTC clearly have bigger Media/outlet and Advertising/outlet effects than those in the lower third quantile (columns 2 vs. 4). ${ }^{21}$ These differences across quantiles suggest

\footnotetext{
${ }^{21}$ We also show the results for the median regression in column 3, which diminishes the effects of outliers on the
} 
that firms with high tradename value, or Media expenditures, are targeting high company ownership_yet within the sectors where we see high values of company ownership (as in the .67 quantile) there is still a big effect of Media on ownership. ${ }^{22}$

In Table 6, we add more explanatory variables to our Tobit regressions, and find that these additional variables also strongly support the hypothesis of managerial targeting of company ownership to control brandname value. ${ }^{23}$ To start with, in all our regressions, Training Required has a very strong and significant positive effect on the proportion of company units-every two days of additional training required by the franchisor raises the target proportion of company units by almost $1 \%$. Of course, firms that place a high value on their brandname must require more training to maintain product quality in close line with company standards. Furthermore, the provision of more training by a franchisor likely reflects a more developed business format and thus stronger brand. In fact, training and media expenditures are highly correlated in our data (a correlation of .52), though their effects are both positive and jointly significant in the regressions.

Similarly, the result that franchisors with physically larger units (higher Capital Required to purchase a franchise or higher Number of Employees per outlet) tend to own more units also supports the tradename value argument: franchisors have more at stake with every unit in chains where units are large, operations are more complex in such units, and they can generate higher

results relative to the standard Tobit regression, and we find no change in the coefficient estimates. Note also that if we drop McDonalds from our data, which is the largest firm and largest Media/outlet expenditures by far, the Media/outlet coefficients rise modestly, but are little changed.

${ }^{22}$ Note that these regressions use the "more conservative" weighted between Tobit estimator, and do not include sectoral dummy variables, because we want to explain the differences across sectors within quantiles, though adding sectoral dummies does not change the nature of the results.

${ }^{23}$ Because adding all these variables jointly considerably lowers the sample size (data for different variables are missing for different chains), we add these variables one at a time and then jointly. When we add them jointly, the much smaller sample size (falling to 930) does lower the significance of all variables. 
externalities. Consequently, we find, consistent with the existing literature, that franchisors protect the brand by operating more of the units directly. ${ }^{24}$ Also, franchisors maintain more company units when they require that franchisees have previous experience (Experience Required) in the business. Again these are businesses where downstream operations are likely to be more complicated and so the franchisor protects its tradename by maintaining direct control over more units.

TABLE 6:

Percent Company OWned Regressions With AdDitional EXPlanatory VARiables

\begin{tabular}{|c|c|c|c|c|}
\hline & \multicolumn{2}{|c|}{ TOBIT } & \multicolumn{2}{|c|}{ BETWEEN TOBIT } \\
\hline & & $\begin{array}{l}\text { All Sector } \\
\text { Dummies }\end{array}$ & & $\begin{array}{c}\text { All Sectors } \\
\text { Dummies }\end{array}$ \\
\hline $\begin{array}{c}\text { TRAINING } \\
\text { REQUIRED } \\
\text { N=5693 }\end{array}$ & $\begin{array}{c}.360 \\
(17.61) \\
\chi^{2}(33)=1117\end{array}$ & $\begin{array}{c}.270 \\
(12.20) \\
\chi^{2}(55)=1431\end{array}$ & $\begin{array}{c}.34 \\
(8.40) \\
\chi^{2}(33)=314\end{array}$ & $\begin{array}{c}.265 \\
(5.83) \\
\chi^{2}(55)=393\end{array}$ \\
\hline $\begin{array}{c}\text { NUMBER OF } \\
\text { EMPLOYEES } \\
\mathrm{N}=3547\end{array}$ & $\begin{array}{c}.452 \\
(15.49) \\
\chi^{2}(25)=710\end{array}$ & $\begin{array}{c}.417 \\
(10.98) \\
\chi^{2}(47)=925\end{array}$ & $\begin{array}{c}.430 \\
(8.93) \\
\chi^{2}(33)=270\end{array}$ & $\begin{array}{c}.428 \\
(6.68) \\
\chi^{2}(55)=351\end{array}$ \\
\hline $\begin{array}{l}\text { CAPITAL } \\
\text { REQUIRED } \\
\mathrm{N}=7670\end{array}$ & $\begin{array}{c}1.0 \\
(5.16) \\
\chi^{2}(33)=1024\end{array}$ & $\begin{array}{c}.57 \\
(2.99) \\
\chi^{2}(55)=1431\end{array}$ & $\begin{array}{c}.90 \\
(2.45) \\
\chi^{2}(33)=255\end{array}$ & $\begin{array}{c}.68 \\
(1.79) \\
\chi^{2}(55)=378\end{array}$ \\
\hline $\begin{array}{c}\text { EXPERIENCE } \\
\text { REQUIRED } \\
\mathrm{N}=4073\end{array}$ & $\begin{array}{c}6.05 \\
(6.90) \\
\chi^{2}(27)=662\end{array}$ & $\begin{array}{c}5.19 \\
(5.91) \\
\chi^{2}(49)=1020\end{array}$ & $\begin{array}{c}8.26 \\
(4.77) \\
\chi^{2}(33)=206\end{array}$ & $\begin{array}{c}7.08 \\
(4.01) \\
\chi^{2}(55)=285\end{array}$ \\
\hline $\begin{array}{l}\text { NUMBER OF } \\
\text { STATES } \\
\text { N=5950 }\end{array}$ & $\begin{array}{c}-.347 \\
(-13.96) \\
\chi^{2}(34)=993\end{array}$ & $\begin{array}{c}.281 \\
(-10.49) \\
\chi^{2}(56)=1380\end{array}$ & $\begin{array}{c}-.305 \\
(-6.23) \\
\chi^{2}(34)=280\end{array}$ & $\begin{array}{c}-.234 \\
(-4.43) \\
\chi^{2}(56)=391\end{array}$ \\
\hline $\begin{array}{c}\text { FINANCING } \\
\text { AVAILABLE } \\
\text { N=7779 }\end{array}$ & $\begin{array}{c}-2.92 \\
(-9.37) \\
\chi^{2}(33)=1085\end{array}$ & $\begin{array}{c}-1.99 \\
(-6.51) \\
\chi^{2}(55)=1704\end{array}$ & $\begin{array}{c}-3.41 \\
(-4.24) \\
\chi^{2}(33)=268\end{array}$ & $\begin{array}{c}-2.33 \\
(-2.89) \\
\chi^{2}(55)=386\end{array}$ \\
\hline $\begin{array}{c}\text { CONTRACT } \\
\text { LENGTH } \\
\mathrm{N}=3690\end{array}$ & $\begin{array}{c}.293 \\
(4.37) \\
\chi^{2}(25)=549\end{array}$ & $\begin{array}{c}.027 \\
(0.38) \\
\chi^{2}(47)=885\end{array}$ & $\begin{array}{c}.201 \\
(2.14) \\
\chi^{2}(33)=214\end{array}$ & $\begin{array}{c}-.011 \\
(-0.11) \\
\chi^{2}(55)=315\end{array}$ \\
\hline
\end{tabular}

Each cell represents a separate regression; the coefficient (t-statistic) is displayed for the variable listed. Each regression also contains the variables listed in regressions of Table 4: Media/outlet in quartic form; advertising/outlet; years before; years before-squared; outlets; outlets-squared; Canadian dummy; year dummies; franchising entry-year dummies.

${ }^{24}$ See Lafontaine and Slade (1997) for a review of the existing literature that shows that this empirical result, that chains with larger units operate more of them directly, is robust across studies in the literature. 
Interestingly, neither of these effects, of outlet size and of previous experience required, on company ownership, is consistent with standard franchisee monitoring arguments. First, larger outlets, whose management requires previous experience, likely means a more difficult job for the manager, so that more franchising should occur in a standard agency model. Second, when outlets are physically large, they tend to be less densely located, with the result that monitoring each outlet is more costly, requiring again more incentive contracting. Our data, however, clearly show that franchisors target more company ownership when each outlet is large and when the manager's job requires previous experience.

Our results on geographical dispersion — the Number of States with outlets—confirm that firms operate less units directly when they are more geographically dispersed. This result is consistent with the use of franchising to give incentives to outlet managers whose actions are difficult to monitor. This finding has been very robust in the literature to date.

Finally, a few words about franchisor financing and contract length. On the former, the negative effect of the provision of Financing Available on the "stable" proportion of company units suggests that this financing relaxes franchisee capital constraints, allowing the franchisor to franchise more. This is in contrast to the argument in the literature where franchisees are viewed as a source of capital for their franchisors. However, as we are dealing with established franchisors, it is not so surprising that they need not rely on franchisee capital for their expansion needs. In fact, such franchisors must find franchising especially valuable if they are willing to provide financing - after all, their capacity to finance franchisees suggests that they have the resources necessary to operate corporately but simply choose not to. As for Contract Length, from a control of the brand perspective, one might expect that long-term contracts are inflexible, so that franchisors should use them less (own a greater proportion of units) if they need to protect 
the brand. Our data show that indeed there is a greater tendency for firms using longer-term contracts to rely on company ownership more. However, the effect of Contract Length becomes insignificant when sector dummy variables are included in the regression. Thus, the effect of Contract Length mostly occurs across sectors and is well captured by sector fixed effects.

Though not shown in Table 6 , it is important to point out that our results concerning our three main measures of tradename value are basically unaffected by the addition of the new explanatory variables of Table 6. In all cases, years spent developing the business before franchising and media expenditures per outlet continue to have strong positive effects on the "stable" proportion of company units. The initial weakness of the Advertising effect means that it does become insignificant in smaller samples for between Tobits.

\subsection{Targeting Managerial Control: Sectoral Differences}

Our regression results clearly show important sectoral differences in the reliance on company ownership. Most likely, these reflect differences in production technology that affect the incentive issues central to franchising. Here we explore these sectoral effects in more detail.

Figure 4 shows the distribution of the proportion of company units for aggregate franchising sectors, with the sectors shown in decreasing order of the proportion of firms within each that have less than 5 percent of company units. ${ }^{25}$ This figure shows remarkable variation in the "target" proportion of company units across these aggregate sectors: the average proportion of company ownership varies importantly across sectors. In a sizable number of sectors, we find very little company ownership — see the results for travel, real estate, contractors, and printing services, where the vast majority of the firms in the sector have less than 5 percent company

\footnotetext{
${ }^{25}$ The data used in this section is for all franchising firms, not just those with more than seven years of experience as in the previous section.
} 
units. About 25 percent of our data fall in sectors with mean company ownership less than ten percent. In contrast, at the other end of the distribution lie all eating establishments—-fast food and full service restaurants—as these all have very high levels of company ownership.

Figure 4: THE Distribution of the Proportion of COMPANy Units ACross Main AGgREGATE SECTORS

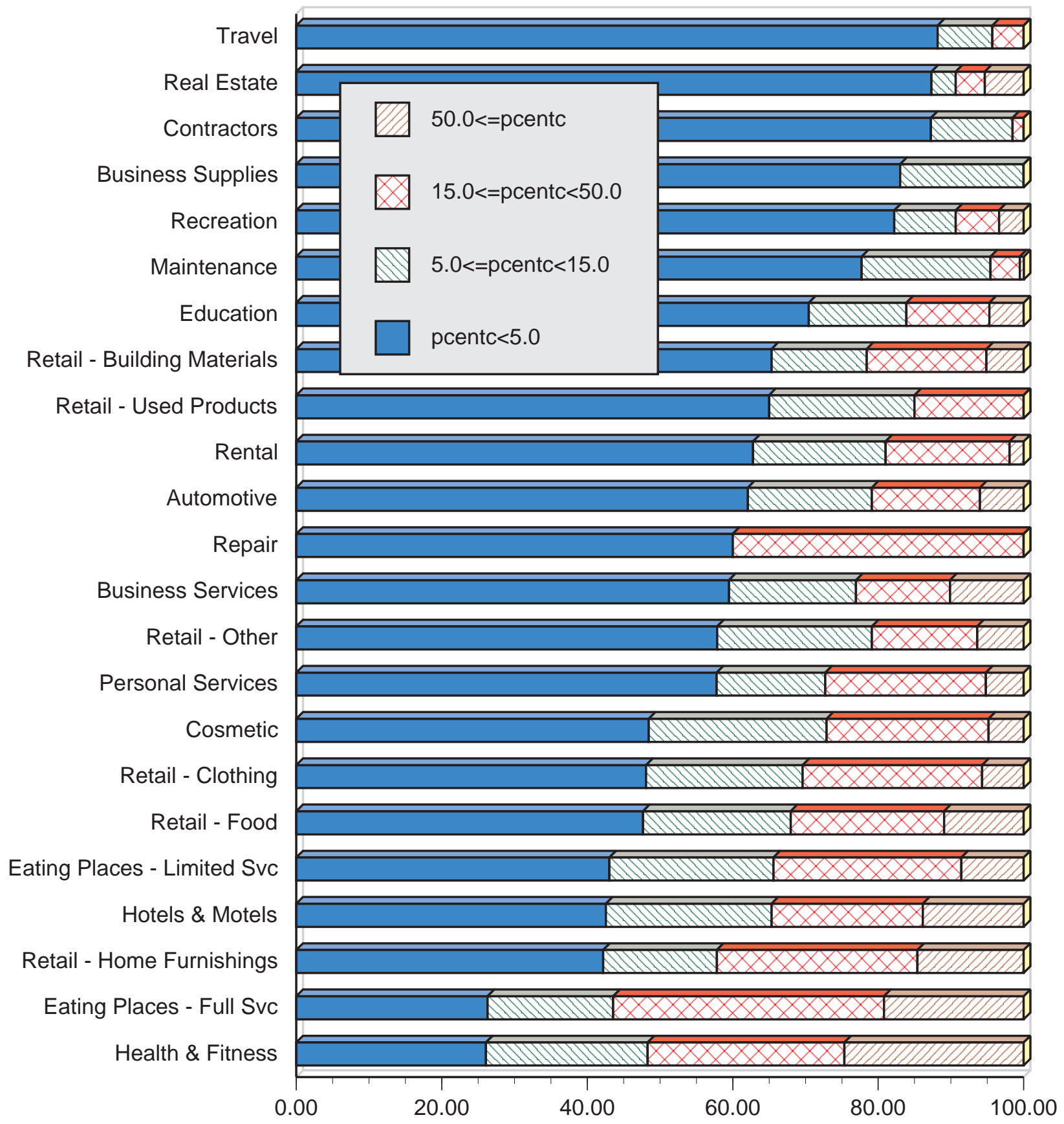


However, Figure 4 also shows significant variation within sectors, as there are firms in each category of percent company ownership in all of the sectors. To determine whether the within-sector variation is due to heterogeneous sector definitions, which would allow for very different types of businesses and production technology to be grouped in the aggregate sectors, we classified all the franchisors in our data into a set of detailed, very homogeneous sectors. For example, in the automotive services sector, we separated out firms involved in "Detailing, Window Tinting, Rustproofing" from "Mufflers Shops" from "Oil Change \& Lube: Shops" from "Transmission repair" and from "Auto Parts Retailing." In total, we created, in this process, 271 separate detailed sectors for business-format franchising. However, because these sectors are so detailed, in many cases we have very few firms per sector. Restricting ourselves to sectors that have 15 or more firms per sector in our data set, the number of sectors falls to 127 , and if we restrict it to those with 20 or more firms, the number of detailed sectors falls to 104 .

Figure 5 displays distributions for the proportion of company units for the largest 25 of those narrowly defined sectors, where the order is again based on the number of firms in the 0 to $5 \%$ category. This figure shows that the variation across such sectors is possibly larger than it was across aggregate sectors. However, the within-sector differences remain very large as well.

To determine the extent of sectoral differences in PCENTC, we created a new data set of sample size 271 containing sector-specific means for all our variables. We then regressed sector means of PCENTC on sector means of all the X variables introduced above. We found that three variables were significant in explaining sectoral differences: media, the number of states, and whether experience was required. ${ }^{26}$

\footnotetext{
${ }^{26}$ For the sample size of 104 sectors, the coefficients (t-statistics) are: .0037 (2.76)*media/outlet - .004(-3.08)*states $+.083(2.18) *$ experience $+.00004(1.69) *$ outlets. Regression results are more significant if more sectors are added.
} 
Figure 5: The Distribution OF THE PROPORTION OF COMPANY UNITS ACROSS THE LARGEST 25 NARROWLY DEFINED SECTORS

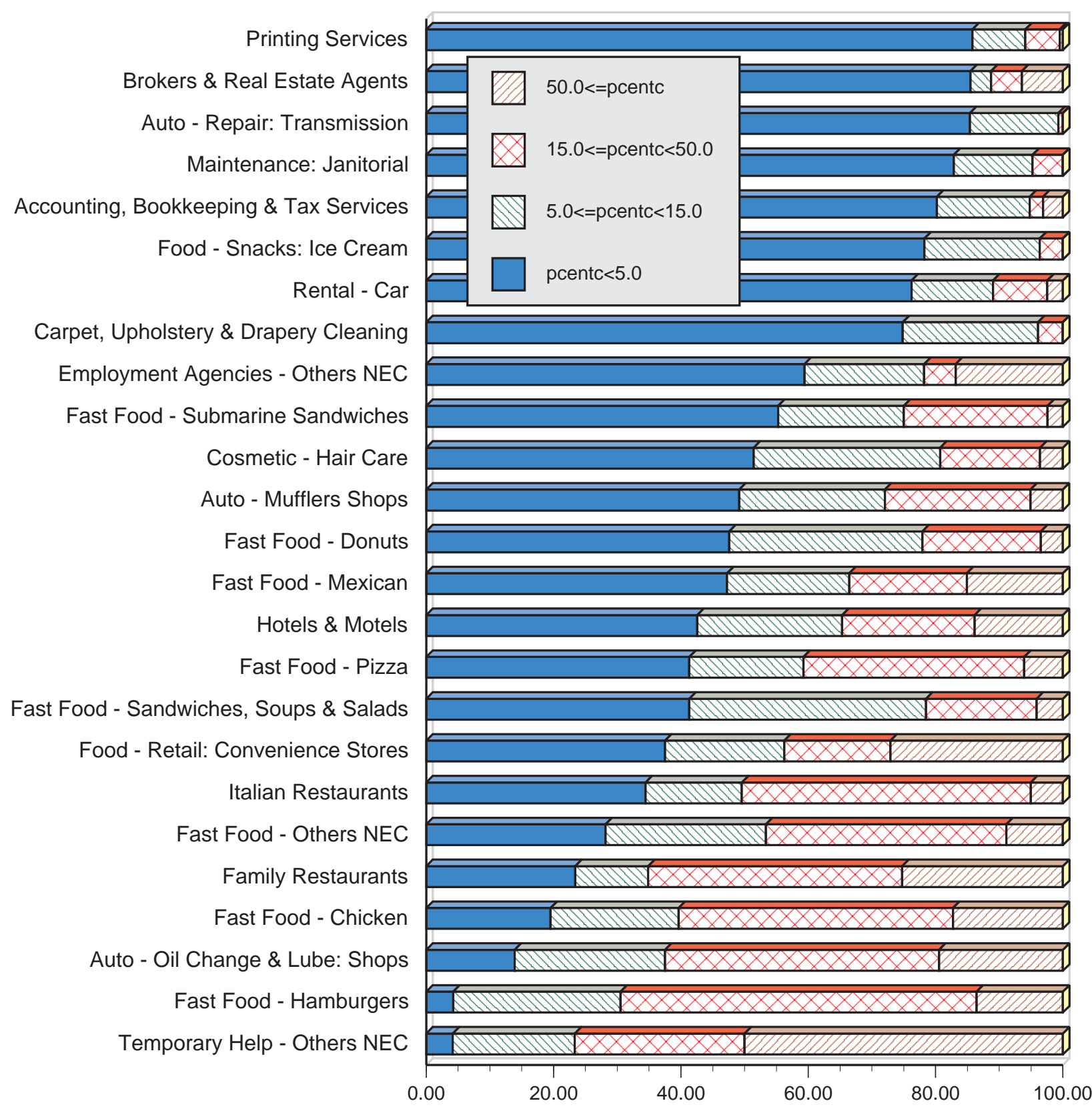

We now turn back to the regressions in Table 4 and introduce detailed sectoral controls in our basic PCENTC regressions. We limit our data set to those firms that belong to one of the 104 detailed sectors with 20 or more firms. As a result, our data set falls from 1563 to 1180

These also contain the variables years-before-franchising and its squared term, advertising/outlet, and year dummies. 
firms. When we add the 23 aggregate sector dummy variables to the percent company owned regression for this data set, the R-squared rises from .17 for the basic regression to .22 . If we instead introduce fixed effects for the 104 detailed sectors the R-squared rises to .35 (or .27 for the adjusted R-squared). ${ }^{27}$ As in Table 4 , the media effect falls very slightly when the main sector dummies are added, and falls slightly more when the detailed sector dummies are added, but in all cases the media effect remains very highly significant.

In sum, we find that the detailed sectoral dummies do add to the explanatory power of the PCENTC regression, but they do not really dampen the media effect, which appears to apply both within narrowly defined sectors and across them. These results are consistent with the sectoral differences shown in Figures 4 and 5-sectoral effects are significant in our regressions, but most of the explained variation in our data occurs within sectors for all explanatory variables other than media, states, and contract length.

\subsection{Targeting Managerial Control: Within-Sector Evidence}

Having shown that within sector variation is an important factor in our data, we now present examples of the targets that are set by firms in a few of the largest franchising sectors, including fast food and auto rental. We are in the very unique position of being able to see and publish the company names for our large data set of more than 1500 firms that have extensive franchising experience-in most other firm-level research with large samples the company names are confidential. The examples below are enlightening and particularly useful in reinforcing the statistical results presented above.

\footnotetext{
${ }^{27}$ Note that if we use the full sample of 1563 and 271 sectoral dummies the R-squared also rises only to .35 (.32 adjusted R-squared). These regressions are between OLS regressions so we can compare the R-squared after adding sectoral dummies, but as is evident in Table 4, there is little difference between the tobits and the OLS models.
} 
TABLE 7: COMPANY LEVEL DATA

\begin{tabular}{|c|c|c|c|c|c|c|c|c|c|}
\hline Company & $\begin{array}{l}\% \text { Co- } \\
\text { own }\end{array}$ & Outlets & $\begin{array}{l}\text { Media } \\
\text { /outlet }\end{array}$ & \# Obs. & Company & $\begin{array}{l}\% \text { Co- } \\
\text { own }\end{array}$ & Outlets & $\begin{array}{l}\text { Media } \\
\text { /outlet }\end{array}$ & \# Obs. \\
\hline \multicolumn{5}{|c|}{ Car Rentals } & \multicolumn{5}{|c|}{ Chicken } \\
\hline Hertz Rent-A-Car & 66.1 & 1601 & 9.07 & 4 & Church's Chicken & 67.3 & 1310 & 4.02 & 17 \\
\hline National Car Rental & 39.5 & 951 & 9.78 & 4 & Grandy's & 52.1 & 164 & 15.63 & 10 \\
\hline Budget Rent A Car & 8.0 & 2937 & 3.99 & 17 & Bojangles of Amer. & 48.6 & 244 & 7.42 & 9 \\
\hline Thrifty Rent-A-Car & 2.6 & 699 & 5.22 & 17 & El Pollo Loco & 38.8 & 245 & 35.71 & 1 \\
\hline Dollar Rent A Car & 1.8 & 1501 & 2.04 & 15 & $\mathrm{KFC}$ & 26.1 & 7976 & 12.18 & 16 \\
\hline Rent-A-Wreck & 1.4 & 314 & 0.25 & 15 & Pioneer Take Out & 24.1 & 288 & 5.35 & 9 \\
\hline $\begin{array}{l}\text { Ugly Duckling Rent- } \\
\text { A-Car System }\end{array}$ & 0.5 & 363 & 0.50 & 9 & $\begin{array}{l}\text { Popeye's Chicken \& } \\
\text { Biscuits }\end{array}$ & 16.4 & 665 & 8.57 & 17 \\
\hline $\begin{array}{l}\text { Holiday-Payless } \\
\text { Rent-A-Car System }\end{array}$ & 0.3 & 182 & 0.00 & 7 & $\begin{array}{l}\text { Lee's Famous Recipe } \\
\text { Country Chicken }\end{array}$ & 14.6 & 262 & 3.47 & 13 \\
\hline $\begin{array}{l}\text { American Intl Rent } \\
\text { A Car }\end{array}$ & 0.1 & 1294 & 0.09 & 11 & $\begin{array}{l}\text { Famous Recipe Fried } \\
\text { Chicken }\end{array}$ & 5.8 & 225 & 1.17 & 2 \\
\hline Econo Car & 0.0 & 161 & 0.00 & 2 & $\begin{array}{l}\text { Golden Skillet Fried } \\
\text { Chicken }\end{array}$ & 2.6 & 159 & 0.96 & 6 \\
\hline \multicolumn{5}{|c|}{ Hamburger } & \multicolumn{5}{|c|}{ Pizza } \\
\hline Carl's Jr. Restaurant & 84.7 & 472 & 13.02 & 8 & Pizza Hut & 49.2 & 4549 & 11.77 & 7 \\
\hline Krystal Restaurants & 81.0 & 308 & 17.87 & 6 & Domino's Pizza & 29.6 & 2919 & 10.90 & 13 \\
\hline Jack in the Box & 80.3 & 864 & 21.10 & 9 & Pizza Inn & 27.8 & 610 & 2.40 & 15 \\
\hline What A Burger & 57.2 & 344 & 5.50 & 7 & Little Caesars Pizza & 27.7 & 1777 & 14.91 & 14 \\
\hline $\begin{array}{l}\text { Checkers Drive-In } \\
\text { Restaurants }\end{array}$ & 56.6 & 169 & 22.71 & 4 & Dino's Pizza & 13.3 & 167 & 0.39 & 5 \\
\hline Burger Chef & 37.0 & 710 & 7.79 & 3 & $\begin{array}{l}\text { Shakey's Pizza } \\
\text { Restaurant }\end{array}$ & 6.9 & 391 & 5.50 & 13 \\
\hline $\begin{array}{l}\text { Wendy's Old } \\
\text { Fashioned Hamb. }\end{array}$ & 31.8 & 3084 & 23.15 & 13 & Round Table Pizza & 1.3 & 472 & 5.36 & 18 \\
\hline Burger Queen & 31.2 & 192 & 3.56 & 1 & $\begin{array}{l}\text { Hungry Howie's } \\
\text { Pizza \& Subs }\end{array}$ & 0.0 & 223 & 1.98 & 8 \\
\hline McDonald's & 26.5 & 11067 & 33.22 & 18 & & & & & \\
\hline Rally's Hamburgers & 25.9 & 282 & 15.36 & 6 & & & & & \\
\hline Burger King & 14.1 & 5366 & 28.79 & 14 & & & & & \\
\hline $\begin{array}{l}\text { Sonic Drive-In } \\
\text { Restaurant }\end{array}$ & 9.8 & 1155 & 5.30 & 16 & & & & & \\
\hline
\end{tabular}

Note: Excludes franchisor with no media data, those with less than 150 units, and Canadian franchisors.. 
In Table 7 we display the company-specific time-series mean values for the key variables (PCENTC, outlet numbers, and media/outlet) in four detailed sectors-namely car rental and then three types of fast-food, chicken, hamburger and pizza—that have high levels of company ownership. We sort the companies by decreasing proportions of company units, and restrict the sample to those firms with more than 150 outlets and 8 years of franchising experience (to limit the size of the table and display only firms committed to franchising).

The most striking evidence comes from auto rental companies. The two companies with the largest per outlet media values, Hertz, and National, target extraordinarily high levels of company ownership (66\% and $40 \%$ respectively). In contrast, a large number of firms target company ownership shares from 0 to 3\% (see American International, Dollar, Holiday, Rent-aWreck, Thrifty, U-Save, and Ugly Duckling). These firms are sizable franchisors, but are investing less in media, thus for those with cross-state coverage, PCENTC is very low. Moreover, the firms that most people perceive as advertising high-quality service (Hertz and National) have much higher levels of company ownership than those firms that advertise lowcost service (such as Budget, Thrifty and Dollar). Similarly, in the fast-food chicken sector, firms that target high levels of company ownership (above 15\%) clearly advertise more, per outlet, on average than those with low levels of company ownership. The same is true in the pizza industry, where the proportion of company units for the three best-known and largest chains, Pizza Hut, Domino's, and Little Ceasar's, are clearly well above those of most chains in the segment. These firms also tend to advertise more than most, on a per outlet basis. Yet it is also true that those smaller pizza chains that also spend a lot on advertising per outlet tend to have high proportions of company units. The evidence is least clear in the hamburgers sector. But 
even here, we see that the established firms, McDonald's and Wendy's, target company ownership levels above 25 percent. $^{28}$ With the exception of Burger King, it is also clear that firms that have high media expenditures per outlet tend to have high proportions of company units.

As we discussed managerial targeting in this section, we presented only averages of the proportions of company ownership over time - space limitations prevent us from displaying time-series company-level data. Of course, our earlier results supported the lack of time-series variation in the proportion of company units in our overall sample, allowing us to concentrate on time-series means. Still, it is worth pointing out again that the companies with high targets of PCENTC that we mention here have especially stable levels of this over time.

In sum, the company examples deepen our interpretation of our Media variable effects on company targeting. We see that companies that target high levels of company ownership due to high Media effects are targeting high-quality tradename values.

\section{CONCLUSION}

Using an extensive longitudinal data set on franchising firms, we show that established franchisors manage their portfolio of company and franchised units to maintain a particular target level of corporate control and ownership. That is, stable franchisors, having eight or more years of experience and at least 15 outlets, maintain a constant percent of company outlets as the franchisor grows or gains experience-company ownership of outlets does not rise or fall with experience or learning, or with success or failure. On average, established franchisors maintain

\footnotetext{
${ }^{28}$ Note that two companies, Carl's Junior and Jack in the Box, have high levels of company ownership because they started franchising much later than they started their business (both started franchising in early 1980's and began business in 1941 and 1951, respectively). During our sample period, as they began franchising, their company
} 
about 15 percent of their outlets as company owned and the other 85 percent are owned by their franchisees. However, this average rate of company ownership varies considerably across sectors, with average rates as high as 26 percent for restaurants and 16 percent for fast food, and as low as 2 percent for travel services. The targeted rate also varies considerably across firms: firm-specific fixed effects explain 90 percent of the variance of company ownership rates in our longitudinal database.

Past empirical work had not identified this practice of targeting a fixed rate of company ownership, and had instead concluded that company ownership declines with experience. Company ownership does decline for the first seven years of experience. Since franchisors start with 100 percent company owned outlets, this proportion can only go down as they add franchised outlets. We find that by the end of seven years, on average, companies have achieved their target rate of corporate ownership and thereafter this rate becomes very stable. However, as mentioned earlier, this conclusion that franchisors choose a particular level of company ownership does not preclude franchisors from choosing which units should be franchised and which company operated.

Given strong evidence that firms target specific but different rates of company ownership, what factors determine firms' optimal targeted rates? We show that brandname value is a primary determinant: franchisors with high brandname value target high rates of company ownership. High rates of company ownership are needed in chains with more valuable brands because each franchisee has an incentive to free-ride on brandname value or undermine brandname value. As each franchisee maximizes outlet profits, he or she receives only a small portion of the return to investing in brandname value, and the remaining return accrues to other 
franchisees or to the franchisor. Thus, when brandname value is high, franchisors must exert more managerial control through their own outlets, by raising rates of company ownership of outlets. Moreover, higher brandname values imply a central role for franchisor effort in generating revenues and furthering the brand through advertising, new product development, and related activities. High rates of company ownership give franchisors a large stake in the business and thus higher-powered incentives to undertake these activities. Hence, both in terms of controlling franchisee free-riding, and in terms of franchisor incentives, one expects higher rates of company ownership in franchised systems with more valuable brands. When brandname value is measured as expenditures on media or advertising, we find that these measures are highly significant determinants of company ownership rates, explaining 11 percent of the variance in company ownership rates across firms. 


\section{REFERENCES}

Anderson, E.E. (1984), "The Growth and Performance of Franchise Systems: Company versus Franchisee Ownership," Journal of Economics and Business, 36, 421-431.

Bai, Chong-en and Zhigang Tao, (2000), "Contract Mix in Franchising," Journal of Economics \& Management Strategy, vol. 9, n.1, p. 85-113.

Bercovitz, J.E.L. (1998b), "Franchising vs. Company Ownership," mimeo, Fuqua School of Business, Duke University.

Bhattacharyya, S. and F. Lafontaine (1995), "Double-Sided Moral Hazard and the Nature of Share Contracts," RAND Journal of Economics, 26, 761-781.

Blair, R. D. and D. L. Kaserman, (1982), “Optimal Franchising," Southern Economic Journal, 494-504.

Blair, R.D. and D. L. Kaserman, (1994), “A Note on Incentive Incompatibility under Franchising," Review of Industrial Organization, 9, 323-330.

Bond, R. (1997), Bond's Franchising Guide, SourceBook Publications.

Bradach, J.L. (1997), "Using the Plural Form in the Management of Restaurant Chains," Administrative Science Quarterly, 42, 276-303.

Bradach, J. L. and R. Eccles (1989), "Price, Authority and Trust," Annual Review of Sociology, 15, 97-118.

Brickley, J.A., (1999), "Incentive Conflicts and Contracting: Evidence from Franchising," Journal of Law and Economics, 42, 745-774.

Brickley, J. and F. Dark (1987), "The Choice of Organizational Form: The Case of Franchising," Journal of Financial Economics, 18, 401-420.

Brickley, J.A., F.H. Dark, and M.S. Weisbach (1991a), “An Agency Perspective on Franchising," Financial Management, 20, 27-35.

Brickley, J.A., F.H. Dark, and M.S. Weisbach, (1991b), "The Economic Effects of Franchise Termination Laws," Journal of Law and Economics, 34, 101-132.

Carmichael, H.L. (1983), "The Agent-Agents Problem: Payment by Relative Output," Journal of Labor Economics, 1, 50-65.

Carney, M. and E. Gedajlovic (1991), "Vertical Integration in Franchise Systems: Agency Theory and Resource Explanations," Strategic Management Journal, 12, 607-629.

Caves, R.E. and W.F. Murphy (1976), "Franchising: Firms, Markets, and Intangible Assets," Southern Economic Journal, 42, 572-586.

Dant, R.P., P.J. Kaufmann and A.K. Paswan (1992), “Ownership Redirection in Franchised Channels," Journal of Public Policy and Marketing, 11, 33-44.

Dnes, A. W. (1992a), Franchising: A Case-study Approach, Ashgate Publishing Ltd., Aldershot, England.

Dnes, A. W. (1992b), "Unfair' Contractual Practices and Hostages in Franchise Contracts," Journal of Institutional and Theoretical Economics, 148, 484-504.

Dnes, A.W. (1993), "A Case Study Analysis of Franchise Contracts”, Journal of Legal Studies, 22, 367-393.

Dnes, A. W. (1996), “The Economic Analysis of Franchise Contracts," Journal of Institutional and Theoretical Economics, 152, 297-324.

Elango, B. and V. H. Fried (1997), "Franchising Research: A Literature Review and Synthesis," Journal of Small Business Management, 35, 68-82. 
Gallini, Nancy T., and Nancy A. Lutz. (1992), "Dual Distribution and Royalty Fees in Franchising," Journal of Law, Economics, \& Organization, 8, 471-501.

Hunt, S.D., (1973), "The Trend Toward Company-Operated Units in Franchise Chains," Journal of Retailing, Summer, 3-12.

Kaufmann, P.J. and Lafontaine, F. (1994), "Costs of Control: The Source of Economic Rents for McDonald's Franchisees," Journal of Law and Economics, 37, 417-543.

Kehoe, M. R. (1996), "Franchising, agency problems, and the cost of capital," Applied Economics, 28, 1485-1493.

Klein, B. (1995), "The Economics of Franchise Contracts," Journal of Corporate Finance, 2, 937.

Lafontaine, F. (1992a), "Agency Theory and Franchising: Some Empirical Results," RAND Journal of Economics, 23, 263-283.

Lafontaine, F. (1992b), "How and Why do Franchisors do What They do: A Survey Report", in P.J. Kaufmann (Ed.), Franchising: Passport for Growth \& World of Opportunity, Sixth Annual Proceedings of the Society of Franchising, University of St-Thomas.

Lafontaine, F. and Bhattacharyya, S., (1995), "The Role of Risk in Franchising", Journal of Corporate Finance, 2, 39-74.

Lafontaine, F. and P.J. Kaufmann (1994), "The Evolution of Ownership Patterns in Franchise Systems," Journal of Retailing, 70, 97-113.

Lafontaine, F. and K.L. Shaw, (1998), "Franchising Growth and Franchisor Entry and Exit in the U.S. Market: Myth and Reality," Journal of Business Venturing, 13,95-112.

Lafontaine, F. and K.L. Shaw, (1999) "The Dynamics of Franchise Contracting: Evidence from Panel Data", Journal of Political Economy, 107, 1041-1080.

Lafontaine, F. and Slade, M.E. (1996), "Retail Contracting and Costly Monitoring: Theory and Evidence", European Economic Review Papers and Proceedings, 40, 923-932.

Lafontaine, F. and Slade, M.E. (1997), "Retail Contracting: Theory and Practice," Journal of Industrial Economics, 45, 1-25.

Lafontaine F. and Slade, M.E., (2001), "Incentive Contracting and the Franchise Decision," for in Advances in Business Applications of Game Theory, K. Chatterjee and W. Samuelson (eds.) Kluwer Academic Press.

Lal, R. (1990), "Improving Channel Coordination through Franchising," Marketing Science, 9, 299-318.

Lewin, S. (1998), "Innovation and Authority in Franchise Systems: An Exploration of the Plural Form," mimeo, Iowa State University.

Lillis, C.M., Narayana, C.L. and J.L. Gilman, (1976), “Competitive Advantage Variation Over the Life Cycle of a Franchise," Journal of Marketing, 40, 77-80.

Love, J.F., (1986), McDonald's: Behind the Arches, Bantam Books, Inc. New York.

Lutz, N.A. (1995), "Ownership Rights and Incentives in Franchising," Journal of Corporate Finance, 2, 103-130.

Luxenberg, S., (1985), Roadside Empires: How the Chains Franchised America, Penguin Books.

Lyons, B.R. (1996), "Empirical Relevance of Efficient Contract Theory: Inter-Firm Contracts," Oxford Review of Economic Policy," 12, 27-52.

Maness, R. (1996), "Incomplete Contracts and the Choice Between Vertical Integration and Franchising," Journal of Economic Behavior and Organization, 31, 101-115.

Martin, R.E. (1988), “Franchising and Risk Management," American Economic Review, 78, 954968. 
Mathewson, F. and R. Winter (1985), "The Economics of Franchise Contracts," Journal of Law and Economics, 28, 503-526.

Minkler, A. (1990), "An Empirical Analysis of a Firm's Decision to Franchise," Economics Letters, 34, 77-82.

Minkler, A. and T. A. Park (1994), “Asset Specificity and Vertical Integration," Review of Industrial Organization, 9, 409-423.

Muris, T.J., D.T. Scheffman, and P.T. Spiller (1992), "Strategy and Transaction Costs: The Organization of Distribution in the Carbonated Soft Drink Industry," Journal of Economics \& Management Strategy, 1, 83-128.

Noren, D.L., (1990), "The Economics of the Golden Arches: A Case Study of the McDonald's System," The American Economist, 34, 60-64.

Norton, S.W. (1988), "An Empirical Look at Franchising as an Organizational Form" Journal of Business, 61: 197-217.

Oxenfeldt, A.R and A.O. Kelly, (1969), "Will Successful Franchise Systems Ultimately Become Wholly-Owned Chains?", Journal of Retailing, 44, 69-87.

Ozanne, U.B. and S.D. Hunt, (1971), The Economic Effect of Franchising, U.S. Senate, Select Committee on Small Business, Washington, Gov. Printing Office.

Rubin, P. (1978), "The Theory of the Firm and the Structure of the Franchise Contract," Journal of Law and Economics, 21, 223-233.

Sasser, W.E. and S.H. Pettway, (1974), "Case of Big Mac's Pay Plans," Harvard Business Review, 52, 30-46 and 156-158.

Schmidt, Torsten (1994), "An Analysis of Intrabrand Competition in the Franchise Industry" Review of Industrial Organization, 9, 293-310.

Scott, F.A. (1995), "Franchising vs. Company Ownership as a Decision Variable of the Firm," Review of Industrial Organization, 10, 69-81.

Shelton, J. (1967), “Allocative Efficiency vs. 'X-Efficiency': Comment," American Economic Review, 57, 1252-1258.

Shepard, A. (1993), "Contractual Form, Retail Price, and Asset Characteristics," Rand Journal of Economics, 24, 58-77.

Slade, M.E. (1996), "Multitask Agency and Contract Choice: An Empirical Assessment," International Economic Review, 37, 465-486.

Thompson, R.S. (1994), "The Franchise Life Cycle and the Penrose Effect," Journal of Economic Behavior and Organization, 24, 207-218.

U.S. Department of Commerce, (1998)Franchising in the Economy, 1986-1988, prepared by Andrew Kostecka. 


\section{Data Appendix}

Our franchisor-level data come from two main sources. For the period from 1980 to 1992 inclusively, the main source of data is the Entrepreneur magazine's "Annual Franchise 500" surveys. In each case, the data for a given year are obtained from the following year survey as these are all published early in the year. In its 1994 survey, which provides data for 1993, the magazine covered fewer firms than usual, and in the 1995 survey onward, it stopped reporting advertising fee data. For those reasons, starting with the 1993 data, we use the Source Book of Franchise Opportunities, now called Bond's Franchise Guide, as our main source of data. This has the added advantage that there is more detailed information on each franchisor in our data from that point onward.

In Table A1, we describe the sample according to the number of years over which we observe each firm in our sample. The change in the composition of our sample of franchisors over time is due first and foremost to entry and exit from franchising. The data reveal that about 15 percent of the franchisors covered in the survey each year have just started franchising. Also, there is considerable exit from franchising: about 140 franchising firms stop operations each year according to the U.S. Commerce Department (1988). The Franchise Annual and the Bond's Franchise Guide report even higher exit rates than that. However, our panel is unbalanced also because we have been fairly conservative in matching firms across years. If we could not find an exact or very convincing match in terms of firm name (and address) over time, we kept the firms separate. Finally, of course, the data are unbalanced also because firms that answer these surveys one year may decide not to respond the next year. Firms are more likely to respond to the surveys when they wish to grow and thus find value in the visibility that these listings provide. Thus, our data are biased in favor of new or expanding firms. 
TABle A1: SAMPle CHARACTERISTICS

\begin{tabular}{cccccc}
\hline Observed & Number of Firms & $\begin{array}{c}\text { Number of } \\
\text { Observations }\end{array}$ & $\begin{array}{c}\text { Started } \\
\text { Franchising in } \\
\text { (mean) }\end{array}$ & $\begin{array}{c}\text { Started in } \\
\text { Business in } \\
\text { (mean) }\end{array}$ & $\begin{array}{c}\text { Number of Firms } \\
\text { (Consecutive } \\
\text { Observations) }\end{array}$ \\
\hline 1 time & 1461 & 1461 & 1984.1 & 1977.6 & 1461 \\
2 times & 944 & 1888 & 1984.3 & 1978.0 & 863 \\
3 times & 578 & 1734 & 1982.8 & 1976.8 & 478 \\
4 times & 475 & 1900 & 1981.9 & 1974.4 & 362 \\
5 times & 293 & 1465 & 1981.7 & 1975.1 & 193 \\
6 times & 216 & 1296 & 1979.6 & 1972.6 & 144 \\
7 times & 176 & 1232 & 1979.4 & 1972.6 & 96 \\
8 times & 136 & 1088 & 1978.1 & 1970.3 & 74 \\
9 times & 92 & 828 & 1978.7 & 1969.3 & 41 \\
10 times & 76 & 760 & 1979.2 & 1970.2 & 37 \\
11 times & 82 & 902 & 1977.8 & 1973.1 & 41 \\
12 times & 59 & 708 & 1976.5 & 1969.4 & 30 \\
13 times & 56 & 728 & 1972.8 & 1965.1 & 21 \\
14 times & 38 & 532 & 1973.0 & 1965.9 & 16 \\
15 times & 41 & 615 & 1974.3 & 1968.4 & 14 \\
16 times & 40 & 640 & 1969.3 & 1962.6 & 19 \\
17 times & 38 & 646 & 1969.9 & 1963.8 & 12 \\
18 times & 41 & 738 & 1965.7 & 1961.8 & 41 \\
\hline Total & 4842 & 19162 & 1982.0 & 1975.4 & 3943 \\
\hline
\end{tabular}

